\title{
KAJIAN INDIKATOR PERINGATAN DINI BANK RUNS DI INDONESIA: PENDEKATAN MARKOV-SWITCHING
}

\author{
Iskandar Simorangkir ${ }^{1}$
}

\begin{abstract}
A run on a particular bank can lead to a banking crisis if it spreads to other banks (contagious effect). In the case of Indonesia, bank runs have also reoccurred time and again. In 1992, bank runs affected several national banks, subsequently precipitating the liquidation of one bank. Then in 1997/ 1998, bank runs developed into the worst banking crisis ever witnessed in the banking history of Indonesia. Considering the extent of losses attributable to bank runs and the banking crisis, extensive studies on the early warning indicators of bank runs are urgently required to prevent future bank runs and banking crises. This paper aims to comprehensively analyse the early warning indicators of bank runs for all banks in Indonesia, both during the sample period of 1990-2005 as well as during the banking crisis in 19971998. The study of early warning indicators of bank runs uses the Markov-Switching model. To calculate the transition probability from a tranquil state to a state of bank run uses the Markov-Switching process through an auto-regressive approach. The change in deposits held at each bank is used as a variable of bank runs. The results of Markov-Switching (MS) show that the MS model is robust as an early warning indicator of bank runs. This is reflected by testing, which was performed on the actual incident of 102 banks, showing that the MS model only produced false signals an estimated $0.69 \%-2.08 \%$ of the time.
\end{abstract}

Keywords: Bank Runs, Early Warning Indicators, Markov-Switching

JEL Classification: C22, G21

1 Director of Economic Research Group at Bank Indonesia, Cental Bank of Republic Indonesia, and Lecturer at MM Graduate School, University of Pelita Harapan, Jakarta, Indonesia; iskandarsim@bi.go.id. The author thanks to the participants of International Conference on Economic Modelling-Ecomod2012, Seville, Spain on July 4-6, 2012. Author also would like to thank Professor Rustam Didong, Dr. Muliaman D. Hadad and Dr. Sugiharso Safuan for valuable comments. The views expressed in this Paper are those of the author and do not necessarily represent those of BI or BI policy. 


\section{PENDAHULUAN}

Bank runs terjadi karena kerentanan bankterhadap penarikan nasabahnya. Kerentanantersebut terkait dengan kegiatan usaha bank yang mentransformasikan kewajiban jangka pendek, seperti giro, tabungan dan deposito ke dalam aktiva yang berjangka waktu lebih panjang, seperti kredit. Dengan kondisi tersebut, bank selalu dihadapi dengan permasalahan maturity missmatch sehingga sangat rentan terhadap penarikan dana besarbesaran (bank runs) oleh nasabah karena terbatasnya aktiva likuid yang dimiliki nasabah. Penarikan simpanan masyarakat besar-besaran tersebut terutama disebabkan penurunan kepercayaan masyarakat terhadap bank. Penurunan kepercayaan terhadap bank dapat berasal faktor internal bank, seperti penurunan kinerja bank, serta faktor-faktor lainnya, seperti memburuknya perekonomian dan faktor eksternal, seperti contagion effect.

Pengalaman empiris menunjukkan bahwa dampak dari bank runs dapat berpengaruh negatif terhadap perekonomian negara khususnya lagi jika terjadi krisis perbankan yang meluas. Krisis perbankan yang berasal dari bank runs mengakibatkan terputusnya fungsi intermediasi sehingga sumber pembiayaan dunia usaha menjadi terhenti. Terhentinya sumber pembiayaan dapat mengakibatkan kegiatan usaha atau produksi terhenti dan pada akhirnya mengakibatkan kontraksi atau perlambatan ekonomi dan peningkatan jumlah pengangguran. Dari sisi fiskal, krisis perbankan akan mengakibatkan tingginya biaya recoveryuntuk penyehatan bank. Kesemua biaya recovery tersebut pada akhirnya akan menjadi beban tax payer atau masyarakat.

Pengalaman krisis di negara-negara Asia pada tahun 1997/1998 menunjukkan bahwa krisis perbankan merupakan salah satu faktor utama yang mengakibatkan negara-negara Asia mengalami kontraksi ekonomi yang cukup parah. Perekonomian Indonesia merupakan perekonomian yang mengalami kontraksi yang paling tinggi, yaitu mencapai $-13,1 \%$ pada tahun 1998. Sementara itu, pertumbuhan ekonomi Thailand, Malaysia, Korea Selatan dan Philipina pada tahun yang sama mengalami kontraksi masing-masing sebesar 10,5\%, 7,4\%, $6,9 \%$ dan $0,6 \%$. Sementara itu, biaya restrukturisasi perbankan pada saat krisis pada negaranegara tersebut mencapai 45\% dari produk domestik bruto untuk Indonesia, 15\% untuk Korea dan 12\% untuk Malaysia (Lindgren et. all. 1999).

Mengingat kejadian bank runs dapat berulang dan dampaknya dapat merugikan perekonomian maka diperlukan kajian mendalam mengenai pengembangan model-model indikator dini untuk mencegah terjadinya bank runs. Pada umumnya penelitian mengenai early warning indicator (EWS) menggunakan dua model utama, yaitu signal extraction model and econometrics model.

Signal extraction model uses non-parametric approach by observing behavior of particular variable before and after crisis. Model yang banyak digunakan dan dijadikan acuan adalah penelitian Kaminsky $(1998,1999)$ untuk indikator peringatan dini krisis nilai tukar dan perbankan dan Kaminsky, Lizondo dan Reinhart (1998) untuk EWS krisis nilai tukar. Model lainnya yang digunakan untuk mendeteksi banking crisis adalah Econometric models, yang salah satunya 
adalah logit model. Demirgüđ-Kunt dan Detragiache (1998) menggunakan logit model untuk mendeteksi terjadinya krisis perbankan. Dalam pendekatan ini, kemungkinan terjadinya krisis diasumsikan merupakan fungsi dari explanatory variable vector, dengan dependent variable adalah 0 jika tidak terjadi krisis dan 1 jika terjadi krisis.

Penelitian terhadap indiKator peringatan dini (IPD) dilakukan beberapa penulis. Penelitian Agung et al. (2003) dan Dewati et al. (2004) membahas indikator peringatan dini krisis nilai tukar dan krisis keuangan Indonesia dengan pendekatan sinyal. Pendekatan ini mempunyai beberapa permasalahan, yaitu berkaitan dengan penetapan batas nilai krisis (threshold) dan jangka waktu krisis yang dilakukan secara arbitrary. Penelitian Bank Indonesia (2003a , 2003b dan 2003c) mengkaji IPD pada stabilitas sistem keuangan dengan menggunakan analisis diskriminan dan regresi logistik, tetapi tidak melakukan penelitian terhadap bank runs. Bank Indonesia (2004a) mengkaji model prediksi kepailitan bank umum di Indonesia dengan menggunakan analisis faktor dan regresi logistik, sedangkan IPD bank runs tidak dibahas.

Dengan latar belakang tersebut, penelitian ini akan mencoba mengembangkan indikator peringatan dini untuk mendeteksi kemungkinan terjadinya bank runs secara individual dengan menggunakan markov-switching model. Bagian kedua dari paper ini membahas landasan teoritis dan beberapa hasil empiris dari penelitian-penelitian sebelumnya. Bagian ketiga menguraikan gambaran kinerja perbankan nasional pada saat krisiss dan model empiris yang digunakan. Hasil empiris penelitianakan disajikan pada bagian keempat, sementara bagian akhir memberikan kesimpulan dan saran-saran untuk mencegah bank runs.

\section{TEORI}

\subsection{Bank Runs and Early Warning Indicators}

Early warning indicators untuk individual bank banyak dibangun dengan kajian empiris awal dilakukan pada pertengahan tahun 1970-an. Penelitian Gonzalez-Hermosillo (1999) menyimpulkan bahwa kejatuhan suatu bank disebabkan kondisi likuiditas, pasar, dan resiko kredit. Ketiga faktor tersebut tentunya dapat dipengaruhi karakteristik individual bank dan kondisi makro ekonomi. Untuk menangkap dampak dari efek yang berbeda-beda GonzalezHermosillo (1999) mengestimasi model regresi dengan menggunakan beberapa indikator perbankan (seperti proxy resiko pasar, resiko kredit, resiko likuiditas dan faktor moral hazard) bersama-sama dengan variabel makro ekonomi dan regional. Penelitian secara tegas menginvestigasi bagaimana kejatuhan suatu individual bank dapat dipengaruhi oleh kerentanan sektor keuangan secara keseluruhan (misal, dengan mempertimbangkan faktor contagion). Secara spesifik, penelitian memasukkan nisbah total kredit terhadap output sebagai pengukuran kerentanan sektor perbankan ke dalam regresi.

Sejalan dengan penelitian yang dilakukan oleh US Federal Deposit Insurance Corporation (FDIC) dalam sistem indikator dini, Gonzalez-Hermosillo (1999) membedakan indikator 
kerentanan yang berasal dari faktor-faktor resiko yang menyebabkan kejatuhan bank. Pada umumnya, peningkatan kredit bermasalah (non-performing loan) dan anjloknya nisbah modal (CAR) merupakan indikasi sebelum bank jatuh. Tetapi hanya sedikit pendapat indikator-indikator penyebab krisis yang utama di dalam memperkirakan terjadinya kejatuhan bank. Beberapa pokok-pokok hasil penelitian tersebut adalah semakin tinggi kredit properti dan penempatan dana antar bank, maka semakin besar kemungkinan kegagalan suatu bank. Sebaliknya semakin tinggi penerimaan kredit dan semakin besar pangsa surat-surat berharga yang dapat diperdagangkan maka semakin kecil resiko terjadinya kejatuhan bank. Sementara itu, faktor contagion mempengaruhi kejatuhan bank dalam beberapa kasus dan pengaruhnya sangat kecil.

Sementara itu, Davis dan Karim (2007) menyebutkan bahwa dalam melakukan studi indikator peringatan dini (IPD) diperlukan pendekatan yang tepat, antara lain dengan menggunakan metode logit dan signal extraction. Perbedaan metode yang digunakan menghasilkan indikator kinerja dan prediksi krisis yang berbeda pula. Metode logit dinilai lebih layak untuk digunakan pada global EWS, sedangkan signal extraction lebih tepat bagi country specific EWS. Seiring dengan perkembangan dan liberalisasi sektor keuangan², penggunaan EWS bagi pencegahan krisis sangat diperlukan.

Demirguc-Kunt dan Detragiache (1999) melakukan studi untuk memprediksi probabilitas krisis perbankan, yang dimaksudkan sebagai alat untuk memonitor kerentanan sektor perbankan. Penelitiannya menggunakan metode multivariate logit dengan panel data, dengan menggunakan variabel yang mencerminkan makroekonomi dan sektor keuangan. Variabelvariabel yang mencerminkan kondisi makroekonomi berupa: pertumbuhan GDP, perubahan terms of trade, depresiasi nilai tukar, inflasi, dan surplus anggaran/GDP. Sementara itu variabelvariabel yang mencerminkan karakteristik sektor keuangan, yakni: M2/cadangan devisa dan tingkat pertumbuhan kredit bank dengan lag dua periode. Di samping itu digunakan GDP per capita sebagai proksi karakteristik struktural perekonomian. Hasil studi tersebut menunjukkan bahwa pertumbuhan GDP yang rendah, tingginya suku bunga riil, inflasi yang tinggi, dan pertumbuhan kredit yang kuat di masa lalu serta besarnya rasio M2 terhadap cadangan devisa secara bersama-sama menyebabkan tingginya terjadi krisis perbankan. Sementara itu, variabel depresiasi nilai tukar, terms of trade, dan surplus anggaran terhadap PDB terlihat tidak signifikan.

Penggunaan regresi probit atau logit dan pendekatan sinyal sebagai indikator peringatan dini mempunyai beberapa kelemahan. Pertama, penentuan tanggal dimulainya krisis yang dilakukan secara arbitrarysehingga kecenderungan penetapan terjadinya krisis menjadi terlambat (Von Hagen dan Ho, 2003). Kedua, pendekatan indikator-indikator dini perbankan dengan menggunakan nisbah penyimpangan (noise) terhadap signal yang benar yang minimal juga

2 Liberalisasi sektor keuangan menurut Karim dan Davis (2007) adalah pemberian kebebasan kepada lembaga keuangan berdasarkan mekanisme pasar dengan menghilangkan hambatan ketentuan dari Pemerintah. 
mempunyai keterbatasan. Keterbatasan tersebut menyebabkan penetapan batas nilai indeks krisis perbankan (threshold) dilakukan secara arbitrary. Beberapa peneliti menetapkan threshold berbeda-beda tanpa memberikan argumentasi yang kuat, seperti Eichengreen, Rose dan Wyplosz (1996) menetapkan krisis threshold sebesar 1,5 standar deviasi dari mean, sementara Kaminsky dan Reinhart (1999) menetapkan krisis threshold sebesar tiga standar deviasi di atas nilai ratarata (mean). Selain itu, threshold dari krisis juga sangat tergantung jumlah sampling yang diambil. Penambahan data atau perpanjangan periode waktu dapat merubah batasan krisis. Kelemahan ketiga adalah transformasi indeks krisis ke dalam bilangan binary dapat mengakibatkan hilangnya informasi yang relevan.

Sejalan dengan kelemahan-kelemahan penggunaan pendekatan probit/logit dan penggunaan secara arbitrary dari batasan (threshold) krisis, maka berkembang penggunaan Markov-Switching model dalam mempelajari krisis nilai tukar maupun krisis perbankan. Penggunaan model ini tidak hanya terbatas digunakan untuk mengidentifikasi periode krisis tetapi juga untuk memperkirakan krisis perbankan yang terjadi. Penggunaan Markov-Switching dalam menganalisis atau mendeteksi terjadinya krisis perbankan mempunyai beberapa keunggulan. Keunggulan pertama, nilai batas indeks krisis (threshold) merupakan variabel endogenous atau dengan kata lain periode krisis dan lamanya krisis merupakan bagian hasil yang diestimasi. Dalam pendekatan ini, ekonomi diasumsikan ke dalam tranquil state atau crisis state. Dengan demikian kedua state ini tidak diobservasi secara langsung dan keduanya merupakan variabel latent. Namun demikian kedua state tersebut indikatornya dapat diobservasi secara langsung dengan melihat perilaku di kedua state ekonomi tersebut. Kedua state tersebut berbeda, dengan state krisis mempunyai nilai lebih tinggi dan berfluktuasi dibandingkan dengan tranquil state (masa normal). Perpindahan nilai dari state yang satu ke state yang lain tergantung dari transition probability. Sesuai dengan karakteristik Markov, nilai yang akan datang suatu state akan tergantung dari state sekarang. Dengan demikian model ini memperkenankan kemungkinan suatu state dalam keadaan krisis akan tetap berada dalam state krisis.

Keunggulan kedua, penggunaan model Markov switching adalah model memperbolehkan penggunaan dependent variable yang kontinyu (continuous dependent variable). Penggunaan perubahan dana pihak ketiga atau indeksnya dapat menghindarkan kehilangan informasi apabila data ditransformasikan dalam bentuk variabel boneka (dummy). Keunggulan ketiga penggunaan model ini adalah model dapat digunakan untuk menangkap informasi dinamis dari krisis. Dengan demikian model ini dapat menginterpretasikan kecenderungan lamanya priode krisis dari probabilitas dari masa transisi. Keunggulan keempat adalah model ini dapat digunakan untuk perilaku yang non linear.

Penggunaan Markov-Switching untuk mendeteksi krisis nilai tukar dan krisis perbankan pada tahun-tahun terakhir semakin berkembang karena terdapatnya kelemahan dalam pendekatan sinyal, yaitu penentuan threshold dari krisis secara arbitrary. Abiad (2003) menggunakan pendekatan Markov-Switching untuk menganilisis sistem peringatan dini 
kemungkinan terjadinya krisis nilai tukar di Asia. Berdasarkan penelitian tersebut didapatkan bahwa model ini bekerja dengan baik dalam mendeteksi krisis nilai tukar di Asia. Model tersebut dapat mendeteksi duapertiga dari periode krisis dalam sampel dan menciptakan sinyal yang salah lebih sedikit dari model dibandingkan model-model sebelumnya, pendekatan sinyal. Penelitian Alvarez-Plata dan Schrooten (2003) dan Ho (2004) juga menghasilkan hasil yang baik (robust) menggunakan model tersebut dalam mendeteksi krisis nilai tukar masing-masing di Argentina dan Asia.

Sementara itu, penggunaan model Markov-Switching untuk krisis perbankan dengan menggunakan data agregat dilakukan oleh Ho (2004). Hasil penelitian tersebut menunjukkan bahwa model tersebut dapat mendeteksi secara baik krisis perbankan di Asia. Untuk Penelitian di Indonesia, Agung et. al. (2003) mengembangkan Sistem Deteksi Dini untuk memprediksi krisis nilai tukar dan krisis perbankan, dengan memodifikasi model ekstraksi sinyal dari Kaminsky, Lizondo, dan Reinhart (1999). Modifikasi tersebut antara lain dengan mencoba menangkap perilaku abnormal dari indikator-indikator yang digunakan tidak secara individual, tapi dengan menggunakan indeks agregatnya. Hal ini dilakukan mengingat menjelang terjadinya krisis biasanya indikator-indikator tersebut akan bergerak searah. Variabel-variabel yang digunakan antara lain: indikator makroekonomi (apresiasi riil mata uang domestik, M2/cadangan devisa) untuk memprediksi krisis nilai tukar; dan indikator mikro agregat perbankan (net interest margin) untuk memprediksi krisis perbankan. Hasilnya menunjukkan bahwa sinyal-sinyal yang dihasilkan dari sistem deteksi dini tersebut menunjukkan hasil yang relatif memuaskan, yakni dengan probabilitas keakuratan masing-masing sebesar $67 \%$ dan $90 \%$.

\subsection{Perkembangan Perbankan Pada Masa Krisis}

Pada awalnya krisis yang melanda perekonomian Indonesia sejak tahun 1997 terutama dipicu oleh krisis nilai tukar rupiah. Tekanan depresiasi nilai tukar rupiah yang besar ini terutama berasal dari faktor contagion dari krisis nilai tukar Baht Thailand pada bulan Juli 1997. Pengaruh contagion tersebut tidak hanya melanda Indonesia tetapi juga dengan cepat meluas ke negaranegara Asia lainnya, seperti Filipina, Malaysia dan Korea Selatan. Dalam rangka menghindarkan perekonomian nasional dari krisis yang lebih dalam sebagai akibat dari tekanan depresiasi nilai tukar dan capital outflow maka Pemerintah mengeluarkan paket kebijaksanaan ekonomi pada September 1997. Selanjutnya, program ini diperluas menjadi program stabilisasi dan reformasi ekonomi yang didukung oleh IMF, World Bank dan ADB secara formal pada November 1997. Sebagai wujud dari pelaksanaan program reformasi di sektor keuangan guna menyehatkan sistem perbankan, maka pada 1 November 1997 sebanyak 16 bank swasta nasional ditutup.

Penutupan 16 bank tersebut mengakibatkan terjadinya bank runs pada bank-bank yang menurut persepsi masyarakat tergolong tidak sehat. Kebijakan penutupan bank yang seharusnya dimaksudkan untuk menyehatkan perbankan nasional justru sebaliknya mengakibatkan 
terjadinya penarikan dana besar-besaran pada bank-bank bukan pemerintah. Penarikan dana besar-besaran ini terjadi karena runtuhnya kepercayaan masyarakat terhadap perbankan akibat penutupan bank tersebut. Semakin meluasnya bank runs tersebut juga disebabkan kinerja keuangan bank yang lemah, seperti peningkatan kredit macet dan menurunnya rentabitas bank, akibat pengelolaan usaha yang tidak sepenuhnya mengikuti hakikat tata kelola yang sehat (Warjiyo, 2001 dan Bank Indonesia, 19983). Selain itu, pesatnya depresiasi nilai tukar rupiah mengakibatkan membengkaknya hutang luar negeri bank dalam denominasi rupiah. Kondisi tersebut diperparah lagi tidak terdapatnya program penjaminan. Di tengah belum terdapatnya program penjaminan dan tidak terdapatnya informasi mengenai kondisi bank (asymmetric information), nasabah bank, khususnya nasabah bank swasta, menarik dana secara besar-besaran dan mengalihkan ke bank yang diperkirakan lebih sehat dan ke aset yang lebih aman (uang kartal).

Satu bulan sejak penutupan 16 bank tersebut di atas (Desember 1997), jumlah dana pihak ketiga yang terdapat di bank umum swasta nasional (BUSN) menurun sebesar Rp 22,9 triliun (11,94\%). Penarikan dana pada umumnya dimulai sejak penutupan bank dan mencapai puncak penarikan tertinggi pada Desember 1997 dan Januari 1998. Penarikan tersebut menurun sejak Pemerintah memberikan jaminan (blanket guarantee) pada Januari 1998. Namun, pada saat terjadi kerusuhan sosial pada Mei 1998, jumlah bank yang mengalami bank runs meningkat kembali.

Berdasarkan data laporan bulanan (LBU) yang disampaikan bank kepada Bank Indonesia, penarikan dana besar-besaran (bank runs) banyak terjadi pada BUSN non devisa ${ }^{4}$, bank beku kegiatan usaha ${ }^{5}$ dan bank beku operasi ${ }^{6}$. Puncak penarikan besar-besaran pada BUSN nondevisa terjadi pada Desember 1997, Januari 1998, dan Mei 1998. Sebagai gambaran, pada Desember 1997, dari 45 BUSN nondevisa, 25 bank mengalami penurunan dana pihak ketiga hingga 10\%, 17 bank mengalami penurunan dana hingga 20\%, 13 bank mengalami penurunan dana hingga 40, 11 bank mengalami penurunan dana hingga $60 \%$, dan 6 bank mengalami penurunan dana hingga $80 \%$ dari total dana bulan sebelumnya.

Sebagaimana di BUSN nondevisa, bank runs juga terjadi di bank beku kegiatan usaha (BBKU) dan bank beku operasi (BBO). Penarikan terbesar terjadi pada November 1997 sampai dengan Januari 1998, dan Maret sampai dengan Mei 1998. Misalnya, pada November 1998, dari 40 BBKU sebanyak 26 bank mengalami penurunan dana pihak ketiga hingga 10\% dari total dana pihak ketiga bulan sebelumnya, 14 bank mengalami penurunan dana hingga 20\% dibandingkan total dana bulan sebelumnya, dan 2 bank mengalami penurunan dana hingga

\footnotetext{
3 Laporan tahunan Bank Indonesia tahun 1997/1998.

4 BUSN non devisa adalah bank swasta nasional yang tidak diperkenankan melakukan kegiatan devisa dalam kegiatan usahanya.

5 Bank beku kegiatan usaha (BBKU) adalah bank yang kegiatan usahanya dibekukan atau tidak diperkenankan untuk melakukan kegiatan usaha sementara waktu atau jangka waktu tertentu.

6 Bank beku operasi (BBO) adalah bank yang kegiatan operasinya dibekukan sementara waktu.
} 
$40 \%$ dibandingkan bulan sebelumnya. Bank runs pada BBO juga tidak jauh berbeda dengan BBKU. Pada Januari 1998, dari 10 BBO, 6 bank mengalami penurunan dana pihak ketiga hingga 20\% dan 4 bank menurun hingga $40 \%$.

Pada periode November 1997 hingga Januari 1998, ketujuh bank pemerintah tidak ada yang mengalami penurunan DPK hingga 10\%. Bahkan sebaliknya, dana pihak ketiga pada bank pemerintah mengalami peningkatan sebesar 9,6\% pada November 1997. Penarikan dana dari bank asing juga tidak jauh berbeda dengan bank Pemerintah. Pada November 1997, hanya satu bank yang mengalami penurunan dana pihak ketiga. Sementara itu, pada Desember 1997 sampai dengan Januari 1998 tidak terdapat penarikan dana pihak ketiga kurang dari 10\%. Bahkan sebaliknya menunjukkan peningkatan sebesar 6,8\% pada November 1997.

Dengan perkembangan tersebut, pangsa dana pihak ketiga bank persero dan bank asing meningkat dari masing-masing sebesar 42,8\% dan 7,2\% pada Desember 1997 menjadi masingmasing sebesar 47,7\% dan 9,3\% pada akhir Januari 1998. Sebaliknya, pangsa dana pihak ketiga BUSN Devisa dan BUSN nondevisa menurun dari masing-masing sebesar 43,2\% dan 2,2\% pada Desember 1997 menjadi sebesar 36,9\% dan 1,5\% pada Januari 1998 (Tabel 3.4). Perkembangan tersebut menunjukkan terdapatnya pengalihan dana dari bank swasta ke bankbank pemerintah dan bank asing.

\begin{tabular}{|c|c|c|c|c|c|}
\hline \multicolumn{6}{|c|}{$\begin{array}{c}\text { Tabel } 1 . \\
\text { Pangsa Dana Pihak III Perbankan }\end{array}$} \\
\hline \multirow{2}{*}{ Kelompok Bank } & Des. 97 & Des. 97 & Jan. 98 & Feb. 98 & Mar. 98 \\
\hline & \multicolumn{5}{|c|}{ Pangsa (\%) } \\
\hline Bank Umum & & & & & \\
\hline 1. Bank Persero & 36,0 & 42,8 & 47,7 & 47,0 & 46,6 \\
\hline 2. BUSN Devisa & 49,7 & 43,2 & 36,9 & 37,1 & 37,6 \\
\hline 3. BUSN Non Devisa & 5,5 & 2,2 & 1,5 & 1,9 & 2,3 \\
\hline 4. BPD & 2,8 & 2,2 & 2,6 & 1,7 & 1,6 \\
\hline 5. Bank Campuran & 1,7 & 2,7 & 3,0 & 3,0 & 2,8 \\
\hline 6. Bank Asing & 4,1 & 7,2 & 9,3 & 9,3 & 9,2 \\
\hline BPR*) & 0,5 & 0,4 & 0,3 & 0,3 & 0,3 \\
\hline
\end{tabular}

Selain pengalihan dana pihak ketiga ke bank-bank tergolong sehat (flight to quality), juga terdapat pengalihan dana ke uang kartal (currency), seperti tercermin dari peningkatan uang kartal pada bulan Januari 1998 sebesar 31,8\% (Rp 9,045 triliun) dibandingkan bulan sebelumnya. Peningkatan tersebut di luar pola normal permintaan uang kartal, yang berdasarkan data dua tahun terakhir sebelum krisis, rata-rata pertumbuhan uang kartal hanya sebesar 9,5\% dalam per tahun. 


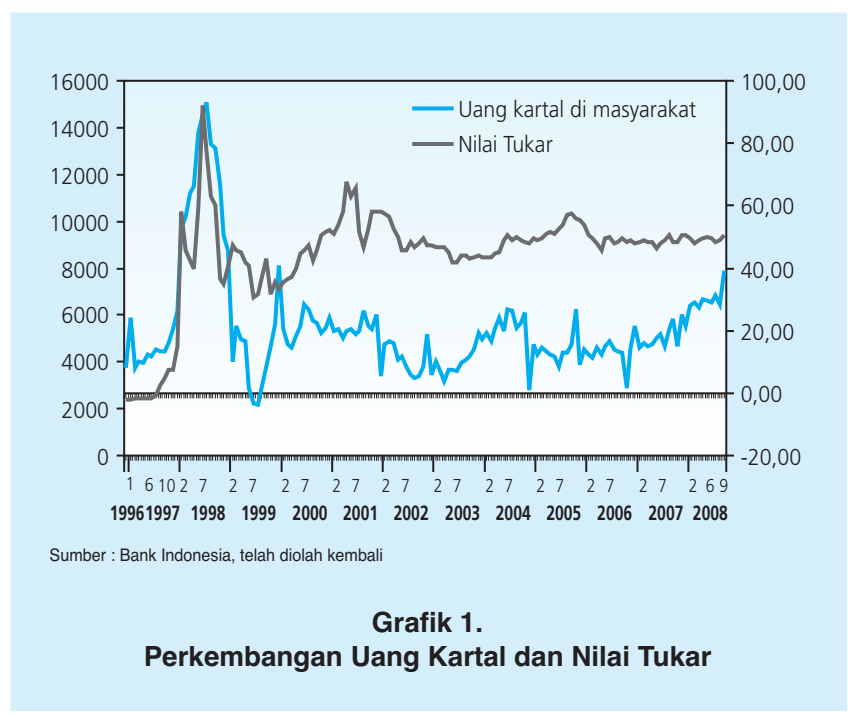

Krisis perbankan tersebut diperberat lagi dengan depresiasi nilai tukar rupiah yang sangat besar. Pada bulan Januari 1997, nilai tukar rupiah terhadap dolarAmerika Serikat (AS) berada pada posisi Rp 2.396. Posisi nilai tukar tersebut terus menurun. Bulan Juli 1997nilai tukar tercatat berada pada posisi Rp 2.599 per dolar AS, dan pada Desember 1997 menjadi sebesar Rp 4.650 per dolar AS. Pada tahun 1998 posisi nilai tukar mengalami penurunan yang sangat drastis, mencapai posisi Rp 10.525 per dolar AS pada bulan Mei 1998 dan terus melemah hingga puncaknya pada bulan Juni 1998 pada posisi Rp 14.900 per dolar AS. Dari posisi tersebut rupiah mulai mengalami penguatan hingga pada bulan Desember 1998 berada pada posisi Rp 8.025 per dolar AS.

Penarikan dana bank secara besar-besaran oleh nasabah dan depresiasi nilai tukar rupiah yang besar memberi tekanan terhadap neraca bank (balance sheet). Kondisi tersebut mengakibatkan kinerja perbankan nasional secara keseluruhan semakin memburuk. Penurunan kinerja perbankan terjadi pada semua aspek keuangan bank, yaitu mencakup permodalan, kualitas aktiva produktif, rentabilitas, dan likuiditas. Kinerja permodalan (CAR) menurun tajam sejak terjadinya krisis, seperti tercermin dari penurunan CAR semua bank dari sebesar 9,19\% pada akhir Desember 1997 menjadi sebesar -15,68\% pada akhir Desember 1998. Demikian halnya kinerja kualitas aktiva produktif (KAP), yang diukur dari perbandingan antara aktiva produktif yang diklasifikasikan tidak lancar dengan total aktiva produktif, meningkat pesat dari sebesar 4,80\% pada akhir tahun 1997 menjadi sebesar 42,39\% pada akhir tahun 1998, sebelum menurun menjadi sebesar 12,74\% pada akhir tahun 1999 sebagai akibat pengalihan kredit bank bermasalah ke BPPN.

Sejalan dengan memburuknya KAP, maka kinerja rentabilitas, yang diukur dengan perbandingan laba dengan aktiva rata-rata (ROA), menurun dari 1,37\% pada tahun 1997 
menjadi -18,76\% pada tahun 1998 dan -6,14\% pada tahun 1999. Kerugian yang dialami hampir semua bank tersebut disebabkan tingginya biaya dana yang ditanggung bank, dengan suku bunga deposito satu bulan mencapai $70 \%$ pada September 1998. Sementara di sisi lain KAP meningkat dan jumlah kredit yang diberikan menurun sejalan dengan kontraksi ekonomi $(13,1 \%$ pada tahun 1998) dan meningkatnya resiko usaha akibat ketidakstabilan sosial, politik, dan keamanan. Sejalan dengan penurunan kredit, maka loan to deposit ratio (LDR) bank juga menurun tajam dari sebesar 86,42\% pada akhir tahun 1997 menjadi sebesar 72,37\% pada akhir tahun 1998 dan hanya sebesar 26,16\% pada akhir tahun 1999.

\section{METODOLOGI}

Model Markov Switching dalam paper ini menggunakan latent variable yang mengikuti turunan pertama dari jalur two-state markov, yaitu. $\left\{s_{t}\right\}_{t=1}^{T} \mathrm{~s}_{\mathrm{t}}=1$ adalah kondisi krisis (crisis state) dan $\mathrm{s}_{\mathrm{t}}=0$ adalah kondisi tenang (tranquil state). Walaupun dalam model ini $\mathrm{s}_{\mathrm{t}}$ tidak diobservasi secara langsung, perilaku dari dependent variable $\left(\mathrm{y}_{\mathrm{t}}\right.$ ) adalah bebas dari $\mathrm{s}_{\mathrm{t}}$ yang dapat dinotasikan sebagai berikut :

$$
y_{t} \mid s_{t} \stackrel{i i d}{\sim} N\left(\mu_{s_{t}}, \sigma_{s_{t}}^{2}\right)
$$

Dependent variable $\left(\mathrm{y}_{\mathrm{t}}\right)$ yang digunakan sebagai indikator peringatan dini bank runs adalah persentase perubahan dana pihak ketiga bank dari tahun 1990-2005. Dengan demikian model Markov-Switching (MS) ini hanya menggunakan univariate model. Pemilihan variabel persentase perubahan dana pihak ketiga bank dengan alasan pertimbangan pengertian bank runs adalah penarikan dana besar-besaran dana pihak ketiga. Dengan sinyal persistensi penurunan dana pihak ketiga, maka dapat diketahui terjadinya bank runs pada suatu bank.

Dalam model MS, nilai rata-rata (mean) dan varian dari $\mathrm{y}_{\mathrm{t}}$ dapat berubah sesuai dengan regime. Densitas (density) dari kondisional $\mathrm{s}_{\mathrm{t}}$ dapat diformulasikan sebagai berikut :

$$
f\left(y_{t} \mid s_{t}\right)=\frac{1}{\sqrt{2 \pi \sigma_{s_{t}}}} \exp \frac{\left\lfloor-\left(y_{t}-\mu_{s_{t}}\right)^{2}\right\rfloor}{2 \sigma_{s_{t}}^{2}}
$$

untuk $\mathrm{s}_{\mathrm{t}}=0,1$

Latent variable dari regime switching, $\mathrm{s}_{\mathrm{t}^{\prime}}$ didapatkan dari matriks transisi probability $\mathrm{P}_{\mathrm{t}}$ sebagai berikut: 
Periode $\mathrm{t}$

State 0

State 1

Periode t-1
State 0 $\left[\begin{array}{cc}p_{00}^{t} & p_{01}^{t}=\left(1-p_{00}^{t}\right) \\ \operatorname{Pr}\left(s_{t}=0 \mid s_{t-1}=0, x_{t-1}\right) & \operatorname{Pr}\left(s_{t}=1 \mid s_{t-1}=0, x_{t-1}\right. \\ =F\left(x_{t-1}^{t} \beta_{0}\right) & =1-F\left(x_{t-1}^{t} \beta_{0}\right) \\ p_{10}^{t}=\left(1-p_{11}^{t}\right) & p_{11}^{t} \\ \operatorname{Pr}\left(s_{t}=0 \mid s_{t-1}=1, x_{t-1}\right) & \operatorname{Pr}\left(s_{t}=1 \mid s_{t-1}=1, x_{t-1}\right) \\ =1-F\left(x_{t-1}^{t} \beta_{1}\right) & =F\left(x_{t-1}^{t} \beta_{1}\right.\end{array}\right]$

dimana $p_{i j}^{t}$ adalah kemungkinan perpindahan dari statei dalam periode $t$ - $l$ ke state $j$ dalam periode $t$ dan $\mathrm{F}$ adalah fungsi distribusi kumulatif normal cdf komponen dari vektor $k x l$ dan $x_{t-1}$ adalah indikator peringatan dini yang dapat mempengaruhi peluang transisi (transition probabilities).

Untuk dapat menjalankan model ini diperlukan nilai awal, yaitu $p_{1}{ }^{1}=\operatorname{Pr}(\mathrm{s}=1)$ yang merupakan unconditional probability menjadi state 1 pada periode 1. Perlakuan terhadap nilai tersebut tergantung stasioner atau tidaknya $x_{t}$. Jika $x_{t}$ adalah stasioner maka probability jangka panjang $p_{1}{ }^{1}$ adalah $\mathrm{s}=1$ dan merupakan fungsi dari $\left(\beta_{0}, \beta_{1}\right)$. Sementara itu, jika $x_{t}$ tidak stasioner maka $p_{1}{ }^{1}$ adalah parameter tambahan yang harus diestimasi. Dalam praktek, jika data runtun waktu cukup panjang maka fungsi likelihood tidak akan terpengaruh baik yang dilakukan dengan menghitung fungsi dari $\left(\beta_{0}, \beta_{1}\right)$ secara terpisah atau ditetapkan nilainya secara tetap tidak membuat perbedaan yang berarti.

Prosedur pendugaan yang digunakan adalah dengan memaksimisasi fungsi likelihood. Fungsi likelihood dihitung dengan menggunakan iterasi yang digunakan oleh Hamilton (1990). Dengan menggunakan informasi yang tersedia hingga periode $t$, kita dapat membentuk $\operatorname{Pr}\left(s_{t}=j \mid \Omega_{t} ; \Theta\right)$, yaitu probabilitas kondisional (filtered) dari observasi $i$ yang dihasilkan oleh rejim $j$, untuk $j=1,2, \ldots \mathrm{N}$. N merupakan jumlah state, dimana dalam penelitian ini digunakan $\mathrm{N}=2$. Selanjutnya probabilitas kondisional tersebut dikumpulkan dalam vektor $(N x 1) \xi_{t \mid t}$.

Pendugaan juga dapat dilakukan melalui probabilitas kondisional (forecast) menjadi rejim $j$ pada periode $t+l$ dengan informasi hingga periode $t$, yang dapat dinotasikan $\operatorname{Pr}\left(s_{t+1}=\right.$ $\left.j \mid \Omega_{t} ; \Theta\right)$, untuk $j=1,2, \ldots \mathrm{N}$. Pendugaan probabilitas tersebut dikumpulkan dalam vektor (NxI) $\xi_{t+1 \mid t}$. Terakhir, $\eta_{t}$ dinotasikan sebagai vektor (Nx1) yang mempunyai komponen sebanyak $j$ adalah merupakan fungsi densitas kondisional dari persamaan (2). Probabilitas yang telah disaring (filtered) dan dihitung untuk setiap periode $t$ dengan melakukan iterasi dari persamaan sebagai berikut : 


$$
\begin{aligned}
& \hat{\xi}_{t \mid t}=\frac{\left(\hat{\xi}_{t \mid t-1} \circ \eta_{t}\right)}{1^{\prime}\left(\hat{\xi}_{t \mid t-1} \circ \eta_{t}\right)} \\
& \hat{\xi}_{t+1 \mid t}=P_{t+1}^{\prime} \hat{\xi}_{t \mid t}
\end{aligned}
$$

dimana $\mathrm{P}_{\mathrm{t}}$ adalah matriks ukuran $\mathrm{NxN}$ dari probabilitas transisi dari periode $\mathrm{t}-1$ hingga periode t sebagaimana dikemukakan dalam persamaan (4) dan 0 adalah notasi perkalian dari masingmasing elemen. Persamaan (5) menghitung $\operatorname{Pr}\left(s_{t}=j \mid \Omega_{t} ; \Theta\right)$ sebagai nisbah distribusi bersama $f\left(y_{t}, s_{t}=j \mid \Omega_{t} ; \Theta\right)$ terhadap distribusi marginal $f\left(y_{t}=j \mid \Omega_{t} ; \Theta\right)$. Distribusi marginal didapatkan dengan menjumlahkan distribusi bersama dari dua state. Persamaan (5) menunjukkan bahwa pada saat didapatkan perkiraan terbaik posisi state saat ini, maka kita cukup mengalikan transformasi matriks $P$ dari probabilitas transisi untuk mendapatkan probabilitas pendugaan dari masing-masing state pada periode berikutnya.

\section{HASIL DAN ANALISIS}

Sebagaimana diuraikan pada pada section 4, untuk menghitung probabilitas transisi dari state tenang (tranquil) ke statebank runs digunakan model Markov-Switching (MS) dengan pendekatan auto regressive, dengan menggunakan proses estimasi menggunakan persamaan (6) hingga persamaan (41). Untuk estimasi digunakan variabel persentase perubahan dana pihak ketiga individual bank (y). Untuk memastikan data stasioner, maka akan dilakukan smoothing data dengan metode Kalman filter. Sementara pengujian validitas dari model MS sebagai indikator dini bank runs akan dilakukan pada setiap individual bank dengan membandingkan dengan kejadian yang sebenarnya.

\section{a. Bank Pemerintah (BP)}

Sinyal terjadinya bank runs pada model Markov-Switching (MS) dilihat dari nilai probabilitas transisi dari state tenang (tidak terjadi bank runs) ke state terjadi bank runs. Nilai probabilitas lebih besar dari 0,5 berarti kemungkinan terjadinya bank runs lebih besar dari 50\% dan nilai 1 berarti kemungkinan terjadinya bank runs mencapai 100\%. Sebaliknya, jika nilainya 0, maka kemungkinan terjadinya bank runs $0 \%$. Hasil model MS pada bank pemerintah menunjukkan sangat jarang terjadi sinyal bank runs ditemukan pada bank tersebut (Tabel 2). Kondisi tersebut tercermin dari nilai probabilitas transisi dari state tenang ke state terjadi bank runs pada hampir setiap bulan hanya sebesar 0. Dari 147 bulan yang diobservasi pada masing-masing individual bank hanya terdapat 16 bulan yang menunjukkan indikasi kejadian bank runs untuk BP1, 7 bulan untuk BP2, 5 bulan untuk BP3, 4 bulan untuk BP4 dan 5 bulan untuk BP5, dengan nilai 
probabilitas pada kisaran 0,7 hingga 1. Namun, sinyal bank runs tersebut tidak persisten (terus menerus) sebagaimana tercermin dari menurunnya nilai probabilitas transisi kejadian bank runs dari kisaran 0,7 hingga 1 menjadi 0 pada bulan-bulan berikutnya.

Sementara itu, pada periode krisis perbankan tahun 1997-1998, model MS tidak menemukan sinyal bank runs pada bank pemerintah sebagaimana tercermin dari nilai probabilitas transisi dari state tenang ke statebank runs sebesar 0 pada periode tersebut. Hasil pengujian terhadap kejadian sebenarnya khususnya pada periode 1997-1998, model MS akurat untuk mendeteksi bank runs. Dari periode observasi (Januari 1988-Maret 2000) terhadap 5 bank pemerintah, hanya 6 bulan $(0,82 \%)$ memberikan sinyal bank runs yang salah (type 2 error) ${ }^{7}$.

\begin{tabular}{|c|c|c|}
\hline \multicolumn{3}{|r|}{$\begin{array}{l}\text { Tabel } 2 . \\
\text { Hasil Markov-Switching Bank Pemerintah }\end{array}$} \\
\hline No & Bank & Bulan Terjadi Sinyal Bank Runs \\
\hline 1 & BP1 & $\begin{array}{l}\text { Apr, May, Aug \& Nov-88, Jan, Apr, Jul, Aug \& Oct-89, Jan, Apr, Jul \& Aug-90, } \\
\text { Feb \& Mar-91, Sept-94 }\end{array}$ \\
\hline 2 & $\mathrm{BP} 2$ & Apr \& Des-91, Oct Nov 92, Des-99, Jan \& Feb-00 \\
\hline 3 & BP3 & Mar \& Apr-91, Oct, Nov \& Des-99 \\
\hline 4 & BP4 & Mar, Apr \& Des-91, Sept-94 \\
\hline 5 & BP5 & Aug-89, Mar, Apr, May \& jul-90 \\
\hline
\end{tabular}

\section{b. Bank Swasta Devisa (BSD)}

Berdasarkan hasil analisis terhadap 26 bank swasta devisa (BSD) dengan menggunakan model MS menunjukkan bahwa sering terlihat sinyal bank runs pada 7 bank (Tabel 3). Kondisi tersebut tercermin dari nilai probabilitas transisi dari state tenang ke state bank runs pada masing-masing bank tersebut berada pada kisaran 0,8 hingga 1 dan angka tersebut cenderung persisten pada beberapa bulan. Berdasarkan kajian terhadap kejadian yang sebenarnya khususnya pada saat krisis perbankan tahun 1997-1998, ketujuh bank tersebut mengalami bank runs. Pada periode sebelum dan sesudah 1997-1998, ketujuh bank tersebut juga sering menunjukkan sinyal terjadinya bank runs dengan nilai probabilitas transisi terjadinya bank runs berada pada kisaran 0,7 hingga 1.

Sementara itu, hasil MS juga menunjukkan terdapat 12 bank yang tidak pernah menunjukkan sinyal terjadinya bank runs, sebagaimana tercermin dari nilai probabilitas transisi bank runs yang sebesar 0. BSD lainnya hanya beberapa kali memberikan sinyal bank runs, namun sinyalnya tidak persisten pada beberapa bulan. Dari total 216 bulan (Januari 1988 -

7 Ukuran sinyal bank runs yang benar adalah bank yang mengalami bank runs dan bank yang menghadapi permasalahan likuiditas akibat penarikan nasabahnya. Nilai 0,82\% didapat dari total sinyal yang salah dibagi total keseluruhan bulan pada 5 bank, yaitu 6 dibagi dengan 735 . 


\begin{tabular}{|c|c|c|}
\hline \multicolumn{3}{|r|}{$\begin{array}{l}\text { Tabel } 3 . \\
\text { Hasil Markov-Switching Bank Swasta Devisa }\end{array}$} \\
\hline No & Bank & Bulan Bank Runs \\
\hline 1 & BSD5 & $\begin{array}{l}\text { Aug-90, Sept-91, Aug, Sept \& Des97, Jan, Feb \& Mar-98, Aug \& Des-00, } \\
\text { Nop \& Des-00, Jan, May, Jul \& Aug-02, Aug-03, Sep-04 }\end{array}$ \\
\hline 2 & BSD10 & $\begin{array}{l}\text { Aug-90, Jun, Jul, Nov \& Des-92, Jan-93, Oct \& Nop-97, Jan, Feb \& Mar-98, } \\
\text { Feb, Sept, Oct, Nov \& Des-99, Feb, Mar, Apr, May, Jun \& Jul-00, Jan, Aug, } \\
\text { Sept \& Oct-01, Aug-02, Aug-03 }\end{array}$ \\
\hline 3 & BSD19 & $\begin{array}{l}\text { Des-88, Oct-89, Jan, Feb \& Sept-90, Nov \& Des-97, Jan, Mar Apr, Jun, Jul \& } \\
\text { Aug-88, Mar, Apr Jun, Jul \& Aug-99, Apr \& May-00, Jul \& Oct-02, Jan, Apr, } \\
\text { Jun \& Aug03, Des-04, Jan \& Nov-05 }\end{array}$ \\
\hline 4 & BSD22 & $\begin{array}{l}\text { Oct-95, Aug \& Sept-98, Mar, Jun \& Jul-99, Sept \& Nov-02, Feb, Mar, Aug, Oct } \\
\text { \& Nov-03, Jan, Apr, May, Nov \& Des-04 }\end{array}$ \\
\hline 5 & BSD23 & $\begin{array}{l}\text { Des-97, Jan, May, Jun, Jul, Sep \& Nov-98, Jan, Feb, Mar, Apr, Jul, Aug, Oct \& } \\
\text { Des-99, Jan, Feb, Mar \& Apr-00, Nov \& des-02,May \& Aug-03, Nov-05 }\end{array}$ \\
\hline 6 & BSD24 & $\begin{array}{l}\text { Feb, Apr, Jun, Aug \& Oct-91, Sept \& Des-92, Mar-93, Feb, Mar, Apr, Jun, Jul } \\
\text { \& Aug-98, Jul-00, Aug \& sept-02, Jan-Oct \& Nov-05 }\end{array}$ \\
\hline 7 & BSD26 & $\begin{array}{l}\text { Sep-88, Oct \& Nov-92, Jan, Apr \& Jun93, Jul-96, Jun \& Jul-98, Mar, Jul \& } \\
\text { Aug-99, Jan, Jul, Aug, Oct, Nov \& Des-03, Feb-05 }\end{array}$ \\
\hline
\end{tabular}

Desember 2005) dan 26 bank, hanya ditemukan total 57 bulan $\left(1,01 \%^{8}\right)$ yang memberikan sinyal yang salah.

\section{c. Bank Swasta Non-Devisa (BSND)}

Berdasarkan hasil MS menunjukkan bahwa dari observasi terhadap 31 bank swasta nondevisa (BSD) sering ditemukan sinyal terjadinya --bank runs pada 20 bank, dengan nilai probabiltas terjadinya bank runs berada pada kisaran 0,8 hingga 1 (Tabel 4). Berdasarkan hasil analisis terhadap kejadian sebenarnya pada tahun 1997-1998, keduapuluh BSND tersebut menghadapi permasalahan bank runs yang cukup berat. Sebelum mengalami bank runs pada tahun 1997-1998, seluruh bank tersebut selalu menunjukkan sinyal bank runsyang cenderung persisten sebagaimana terlihat dari nilai probabilitas transisi terjadinya bank runs yang berada pada kisaran 0,9 hingga 1. Sinyal yang sama masih berlanjut hingga tahun 2000, dengan besaran sinyal bank runs yang cenderung menurun, dengan nilai probabilitas transisi pada kisaran 0,8 hingga 1.

Sementara 11 bank BSND lainnya juga menunjukkan sinyal terjadinya bank runs, namun tidak sesering keduapuluh BSND di atas. Selain itu, nilai probabilitas transisi dari kesebelas bank tersebut juga lebih rendah, dengan nilai pada kisaran 0,6 hingga 1. Pada krisis perbankan

8 Dihitung dari total sinyal yang salah dibagi dengan total bulan observasi dikalikan dengan jumlah bank. Dengan demikian, angka $1,01 \%$ di atas didapat dari $57 /(216 \times 26)$. 
tahun 1997-1998, kesebelas bank tersebut tidak menghadapi permasalahan bank runs. Berdasarkan hasil perbandingan dengan kejadian sebenarnya, hasil MS memberikan sinyal yang salah pada 94 bulan (1,4\%). Dengan demikian, hasil MS masih tergolong akurat digunakan untuk mendeteksi terjadinya bank runs.

\begin{tabular}{|c|c|c|}
\hline \multicolumn{3}{|r|}{$\begin{array}{l}\text { Tabel } 4 . \\
\text { Hasil Markov-Switching Bank Swasta Non Devisa }\end{array}$} \\
\hline No & Bank & Bulan Bank Runs \\
\hline 1 & BSND2 & Des-88, Jul, Oct \& Des-93, Feb, Apr, Jul \& Sept-95, Nov-Des-97, Jan-98 \\
\hline 2 & BSND3 & $\begin{array}{l}\text { Des-88, De93, Nov \& Des-94, Feb, Mar, Apr, Jun \& Sept-95, Feb \& Mar99, } \\
\text { Oct \& Nov-01, Des-02, Des-03 Des-04, Jan, Jun \& Jul-05 }\end{array}$ \\
\hline 3 & BSND6 & $\begin{array}{l}\text { Mar, Nov \& Des-88, Des-93, Jan, Sept, Oct, Nov \& Des-94, Feb, Mar, Apr, } \\
\text { Jun, Aug \& Sept-95, Nov \& Des-97, Mar-99, Nov-01 }\end{array}$ \\
\hline 4 & BSND7 & $\begin{array}{l}\text { Mar, Jun, Sept \& Des-88, Oct-89, Nov \& Des-93, Des-94, Apr, Jul, Aug } \\
\& \text { Sept-95, Oct \& Nov-97, Jan-98, Feb, Mar, May, Jun, Jul, Aug \& Nov-99, } \\
\text { Oct, Nov-01, Jan-03, Jan-04, Jan-05 }\end{array}$ \\
\hline 5 & BSND9 & $\begin{array}{l}\text { Mar, Jul, Nov \& Des-88, Jan-90, Apr-92, Jul-93, Des94, Apr \& Sept- } \\
\text { 95, Nov \& Des-97, Feb-99 }\end{array}$ \\
\hline 6 & BSND10 & $\begin{array}{l}\text { Mar, Jun \& Nov-88, Jan, Apr, Jul, Oct \& Des-91, Feb, Apr, Jul, Aug, Oct \& } \\
\text { Nov-92, Jan, Feb, Apr, May, Jul \& Sept-93, Mar, Apr, Sept, Nov \& Des-94, } \\
\text { Feb, Mar, Apr, Aug \& sept-95, Des-97, Jul-98, Feb, Mar Jul \& Oct-99 }\end{array}$ \\
\hline 7 & BSND11 & $\begin{array}{l}\text { Aug, Sept \& Oct-88, Jan, Aug \& nov-91, Apr, May, Jun, Jul, Aug, Sept \& Des- } \\
\text { 92, Feb, Apr, May, Jul, Nov \& Des-93, May, Jul, Sept, Oct \& Des-94, Feb, } \\
\text { Apr, Jun \& Sept-95, Feb, Apr, May Jun, Jul, Nov \& Des-96, Jul, Sept \& Nov- } \\
\text { 97, May, Jun, Aug, Sep, Oct \& Des-99, Jun-00 }\end{array}$ \\
\hline 8 & BSND14 & $\begin{array}{l}\text { Des-91, Des-93, Feb, Apr, Nov \& Des-94, Mar, Apr, Jul \& Sept-95, Jan, } \\
\text { Aug, Sept, Nov \& Des-97, Apr, May, Jul Oct-98, Mar, Apr \& May-99 }\end{array}$ \\
\hline 9 & BSND16 & $\begin{array}{l}\text { May \& Jul-88, Jul, Nov \& Des-93, Jul, Sept \& Oct-97, Des-98, Jan, Mar, } \\
\text { Apr \& May-99 }\end{array}$ \\
\hline 10 & BSND17 & $\begin{array}{l}\text { May-88, Nov-92, Feb, Jul, Sept \& Des-93, Mar, Apr, Jun \& Des94, Feb, } \\
\text { Mar, Apr, Jun \& Sept-95, Aug, Sept \& Oct-97, May, Aug, Sept, Oct \& Des- } \\
\text { 98, Jan, Apr, May, Aug \& Oct-99, Jan, Feb, Mar, May-00 }\end{array}$ \\
\hline 11 & BSND18 & $\begin{array}{l}\text { Jun, Jul, Oct \& Nov-88, Jan-92, Jun, Jul, Sept, Nov \& Des-93, Nov \& Des-94, } \\
\text { Mar, Apr \& Sept-95, Jan, Mar, Jun, Aug, Oct \& Nov-98, Jan, Feb \& Mar-99 }\end{array}$ \\
\hline 12 & BSND19 & $\begin{array}{l}\text { May, Jul, Sept \& Nop-88, Jan, Apr \& May-92, Jan, Feb, Jul, Sep, Oct \& Des- } \\
\text { 93, Jan, Feb, Mar, Apr, Jul, Aug, Sept \& Des-94, Feb, Jun, Jul \& Sept-95, Mar, } \\
\text { Apr, Jul, Sept Nov-96, Jan, Feb, Apr, Jul, Aug, Sept, Oct \& Nov-97, Mar, Apr, } \\
\text { Jun, Sept, Oct \& Nov-98, Jan, Apr Sept \& Oct-99, Feb \& Jul-00 }\end{array}$ \\
\hline 13 & BSND20 & $\begin{array}{l}\text { Jul \& Aug-88, Jan, Apr, Jul \& Aug92, Feb, Apr, Jul, Aug \& Des-93, Mar, Apr, } \\
\text { May, Jul, Sept \& Des-94, Mar, Apr \& Sept-95, Mar \& Nop-96, Jan, May, Jun, } \\
\text { Jul \& Oct97, Jan, Jun, Jul, Aug, Sept, Oct \& Nov-98, Jan, Feb, Mar, Jul, Sept } \\
\& \text { Oct-99 }\end{array}$ \\
\hline 14 & BSND21 & $\begin{array}{l}\text { Mar, May, Jul, Oct \& Nov-88, Oct-92, Mar \& Des-93, Nov \& Des94, Apr, Jul \& } \\
\text { Sept-95, Des-97, Jan-98, Feb-99, Jul-00 }\end{array}$ \\
\hline 15 & BSND22 & $\begin{array}{l}\text { Mar \& Jul-88, Jan, Jul, Sept \& Des-93, Mar, May, Jul, Aug \& Des-94, Mar, Apr, } \\
\text { Jun, Jul, Aug, Sept, Nov \& Des-95, Mar, May, Jun, Jul, Oct \& Des-96, May, Oct } \\
\& \text { Nov-97, Mar, May, Aug, Nov \& Des-98, Jan, Mar, May, Jun, Jul, Sept \& Des99, } \\
\text { Jan, Feb \& Mar-00 }\end{array}$ \\
\hline 16 & BSND25 & $\begin{array}{l}\text { Mar, May \& Jun-88, Oct \& Des-93, Oct \& Des-94, Jan, Apr, Jul \& Sept-95, Oct } \\
\& \text { Nov-97, Jan, May, Jul, Aug, Sep, Oct \& Des-98, Apr \& Jul99 }\end{array}$ \\
\hline 17 & BSND26 & $\begin{array}{l}\text { Sep \& Nop88, Jan, Jul \& Des-93, Mar, Aug, Oct \& Des-94, Jan, Apr, Sept \& } \\
\text { Des-95, Mar-96, Feb, Oct \& Nov-97, Jan, May, Jun \& Aug-98, Jan, Mar, Jul } \\
\text { \& Des-99, Feb, Mar, May \& Jun-00 }\end{array}$ \\
\hline
\end{tabular}




\begin{tabular}{c|c|l}
\hline 18 & BSND27 & $\begin{array}{l}\text { Jul \& Sept-98, Jan \& Jul-93, Apr \& Des-94, Apr, Sept \& Nov-95, Jan, Feb, Apr, } \\
\text { May, Jun, Jul, Sept, Oct, Nov \& Des-96, Sept \& Des-97, Jan, May, Jul, Sept \& } \\
\text { Des-98, Feb, Mar, Apr, May, Aug, Nov \& Des99, Jul-00 }\end{array}$ \\
\hline 19 & BSND29: & $\begin{array}{l}\text { May, Jun, Jul \& Nov-88, Mar, Jun, Aug, Nov \& Des-94, Feb, Apr, Jul, Aug \& } \\
\text { Sept-95, Aug, Sept, Oct \& Nov-97, Apr, May, Aug, Sept Nov-98, Feb, Mar, } \\
\text { May, Jun, Jul, Sept \& Oct-99, Mar-00 }\end{array}$ \\
\hline 20 & BSND31: & $\begin{array}{l}\text { Apr, Jul \& Des-94, Mar, Apr, Sept, Nov \& Des-95, Jan, Apr, May, Aug, Oct \& } \\
\text { Nov-96, Feb, Apr, Aug, Nov \& Des-97, Jun, Aug, Oct Des-98, Jan, Apr, May \& } \\
\text { Aug-99, Feb, Mar \& Jun-00 }\end{array}$ \\
\hline
\end{tabular}

\section{d. Bank Asing}

Hasil Markov-Switching (MS) menunjukkan bahwa terdapat 4 dari 6 bank asing yang diobservasi sering menunjukkan sinyal bank runs dengan nilai probabilitas transisi dari state tenang ke statebank runs berada pada kisaran 0,6 hingga 1 (Tabel 5). Pada periode krisis perbankan tahun 1997/1998, berdasarkan model MS, keempat bank tersebut mengalami bank runs. Sementara dua bank lainnya, relatif tidak pernah memberikan sinyal bank runs sebagaimana tercermin nilai probabilitas transisi terjadinya bank runs yang menunjukkan angka sebesar 0 . Kejadian sebenarnya juga menunjukkan bahwa kedua bank ini tidak pernah mengalami bank runs.

Secara keseluruhan dari data yang diobservasi pada periode Januari 1988 hingga Desember 2005, hasil MS memberikan total sinyal yang salah sebanyak 27 bulan kejadian atau 2,08\% dari total 6 bank dan 216 bulan yang diobservasi. Dengan demikian, sinyal dari model MS pada bank asing cukup akurat dalam dalam memantau kemungkinan terjadinya bank runs pada salah satu bank.

\begin{tabular}{|c|c|c|}
\hline \multicolumn{3}{|r|}{$\begin{array}{l}\text { Tabel } 5 . \\
\text { Hasil Markov-Switching Bank Asing }\end{array}$} \\
\hline No & Bank & Bulan Bank Runs \\
\hline 1 & BA1 & $\begin{array}{l}\text { Jan, Apr, May, Sept \& Des-90, Jan, Feb, Mar, Jun \& Jul-91, Jul \& Sept-97,Jun, } \\
\text { Jul, Aug \& Sept-98, Jan, Aug, Sept \& Oct-02, Jan, Feb \& May 03, Jan, Mar, Apr, } \\
\text { Aug \& Nop-04, Feb, Jun, Jul \& Aug-05 }\end{array}$ \\
\hline 2 & BA2 & $\begin{array}{l}\text { Feb, May, Sep, Oct \& Nop-89, Jan, Mar, Apr, Jun, Jul, Aug \& Oct-90, Jan, Apr, } \\
\text { Aug, Sept \& Nop-93, Jan, Apr, Aug, Sept \& Nop-93, Feb, Mar, Apr, Jul, Oct \& Des- } \\
\text { 95, Jan Feb, Mar, Apr \& Aug 96, Jan, Mar, Apr, Jun, Jul, Aug \& Oct-97, Feb, Jul, } \\
\text { Aug, Sept \& Nop-98, Feb, May, Jun \& Aug-00, Jan, Feb, Mar, Jun, Jul, Aug, Oct \& } \\
\text { Des-01, Jan, Feb, Mar, Apr, Jul, Aug, Oct-02, Apr, May \& Jul-03, Jan, Feb, Mar, } \\
\text { Apr, Jun, Sep \& Oct-04, Jan, Feb, Mar, Apr \& Aug-05 }\end{array}$ \\
\hline 3 & BA3 & $\begin{array}{l}\text { Apr, Jul \& Des-93, Feb, Mar, May, Jun, Sept, Oct \& Nov-94, Jan, Mar, Apr, Apr, } \\
\text { Jul, Aug \& Oct-95, Feb, Mar, May, Jun \& Aug-96, Feb, Aug, Sept, Oct-97, Apr, } \\
\text { Jun, Jul, Aug, Sept, Oct \& Des-98, Jun-99, Feb-02, Jul, Sept \& Oct-04, Jan, Jun } \\
\text { \& Jul-05 }\end{array}$ \\
\hline 4 & BA4 & $\begin{array}{l}\text { Jun, Aug, Oct \& Des-89, Jan, Apr, May, Jun \& Aug-90, May, Aug, Oct \& Des-93, } \\
\text { Feb \& Mar-94, Jul, Oct \& Des-95, Feb \& Mar-96, Jun \& Oct-97, Apr, Jun, Jul \& } \\
\text { Aug-98, May, Jun \& Aug-05 }\end{array}$ \\
\hline
\end{tabular}




\section{e. Bank Campuran (BC)}

Hasil MS untuk kesembilan bank campuran (BC) yang diobservasi menunjukkan sinyal terjadinya bank runs pada periode krisis perbankan 1997-1998, dengan nilai probabilitas transisi sebesar 1, yang berarti 100\% kemungkinan terjadinya bank runs. Hasil tersebut sejalan dengan kejadian yang sebenarnya, dimana 9 bank tersebut mengalami kejadian bank runs. Sementara itu, dilihat dari sering terjadinya sinyal bank runs, terdapat 4 bank yang sering mengalami bank runs (Tabel 6) dengan nilai probabilitas kejadian bank runs berkisar antara 0,7 hingga 1.

Hasil perbandingan dengan kejadian yang sebenarnya menghasilkan sinyal yang salah sebanyak 18 bulan atau 0,93\% dari total bank dan bulan yang diobservasi. Hasil MS dari bank campuran ini juga menunjukkan bahwa model MS cukup akurat digunakan sebagai indikator peringatan dini terjadinya bank runs pada masing-masing individual bank.

\begin{tabular}{|c|c|c|}
\hline \multicolumn{3}{|r|}{$\begin{array}{l}\text { Tabel } 6 . \\
\text { Hasil Markov-Switching Bank Campuran }\end{array}$} \\
\hline No & Bank & Bulan Bank Runs \\
\hline 1 & BC2 & $\begin{array}{l}\text { Apr, Aug, Oct, Nov \& Des-90, Feb, Mar, Apr, May, Aug, Sept \& Nov-91, Jan, Mar, } \\
\text { Jul, Aug \& Oct-92, Jan, Feb, May, Jul, Aug \& Oct-93, Jan, Mar, Apr, Jun, Jul, Aug } \\
\text { \& Oct-94, Jan, Feb, Mar-95, Sep, Oct, Nov \& Des-96, Feb, Mar, Apr, May, Aug \& } \\
\text { Nov-97, Feb, Mar, Apr, Jul, Oct, Nov \& Des-98, Jan, Feb, Apr, May \& Aug99, } \\
\text { Sept-04, Jan, Feb, May-05 }\end{array}$ \\
\hline 2 & BC5 & $\begin{array}{l}\text { May, Aug \& Nop90, Mar, Apr, May, Jul \& Oct-91, Jan, Apr, May, Jun, Jul \& Aug- } \\
\text { 04, Aug, Sept \& Nov-97, Feb, Apr, Jun, Jul \& Sept-98 }\end{array}$ \\
\hline 3 & $\mathrm{BC} 6$ & $\begin{array}{l}\text { Des-89, Jan, Apr, May, Jul, Aug, Oct, Nov Des-90, Jan, Apr, May, Jun, Nov \& Des- } \\
\text { 91, Jan, Apr, Jun, Aug \& Oct-92, Jan, Apr, May, Jun, Jul, Oct \& Des-93, Mar, } \\
\text { Apr, Jul, Aug, Oct, Nov \& des-94, Feb, Mar, Apr, Jun, Jul, Sept, Oct \& Des-95, Jan, } \\
\text { Mar, Apr, jul, Aug \& Des-96, Feb, Jul, Sept \& Oct97, Jan, Mar, Apr, May, Jul, Sept, } \\
\text { Oct, Nov \& Des-97, Feb, Mar, Apr, Jun, Jul \& Des-99, Feb, Mar, Jun, Jul, Aug \& } \\
\text { Des-00, Jan-01 }\end{array}$ \\
\hline 4 & $\mathrm{BC} 7$ & $\begin{array}{l}\text { Jul \& Oct-90, Jan, Apr, May, Jun, Aug \& Nov-91, Jan, Sept \& Oct-92, Jan, Feb, } \\
\text { Mar, Apr, May, Jun, Jul, Aug, Sept \& Oct-93, Mar, Apr \& May-94, Apr, Jun, Aug, } \\
\text { Oct, Nov \& Des-95, Jan, Mar, May, Jun, Sept, Oct \& Nov-96, Jan, Mar, May, Jun, } \\
\text { Sep, Oct \& Nov-97, Apr, Jun, Jul, Oct \& Nov-98,Mar, Jun, Aug-99, Mar, May, Jul } \\
\text { \& Aug-03, Jan, Mar, Apr \& Des-04, Apr, Jun \& Jul-05 }\end{array}$ \\
\hline
\end{tabular}

\section{f. Bank Beku Kegiatan Usaha (BBKU)}

Dari 8 bank beku kegiatan usaha yang dianalisis dengan model MS, hanya dua yang tidak menunjukkan sinyal bank runs pada periode krisis perbankan tahun 1997-1998, sementara 5 bank lainnya menunjukkan sinyal terjadinya bank runs (Tabel 7), dengan nilai probabilitas transisi terjadi bank runs berada pada kisaran 0,9 hingga 1 . Sinyal bank runs sering terjadi pada BBKU 2 dan 3, dengan nilai probabilitas transisi terjadinya bank runs berada pada kisaran 0,9 hingga 1 . Kondisi tersebut sejalan dengan kejadian sebenarnya dimana terjadi bank runs pada periode tersebut. 
Perbandingan kejadian sebenarnya berdasarkan full sample, masih terdapat 12 bulan kejadian atau 0,69\% dari total observasi yang menunjukkan sinyal yang salah terhadap kejadian bank runs. Kesalahan sinyal tersebut terjadi pada 4 bank. Dengan melihat kecilnya selisih kesalahan antara hasil MS dengan kejadian sebenarnya, maka model MS dapat digunakan sebagai indikator untuk mendeteksi bank runs pada bank-bank yang bermasalah dan indikator individual pengawasan bank lainnya.

\begin{tabular}{c|c|l}
\multicolumn{3}{|c}{ Hasil Markov-Switching Bank Beku Kegiatan Usaha (BBKU) } \\
\hline No & Bank & \multicolumn{1}{c}{$\begin{array}{l}\text { Tabel 7. } \\
\text { Bulan Bank Runs }\end{array}$} \\
\hline 1 & BBKU1 & Aug -89 \\
\hline 2 & BBKU2 & $\begin{array}{l}\text { Aug \& Oct-89, Jan, Jul, Aug \& Nop-90, Jan, Feb, Apr, Jul, Aug \& Oct-91, } \\
\text { Des-92, Jan, Jul \& Aug-93, Jan-94, Oct, Nov \& Des-98 }\end{array}$ \\
\hline 3 & BBKU3 & Mar \& Nop-88, Jul \& Aug-90, Jul, Aug \& Des-91, Oct, Nov \& Des-92, Nov 98 \\
\hline 4 & BBKU4 & Nov-88, Jul \& Aug-90, Nov \& Des-92, Des-93, Des-98 \\
\hline 5 & BBKU5 & Aug-89, Sep-92, Des-93, Sep \& Oct-94, Feb, Apr \& Jun-96 \\
\hline 6 & BBKU6 & Oct, Nov \& Des-88, Jan \& Oct-89, Des-98 \\
\hline 7 & BBKU7 & Mar, May, Jun, Aug, Sep, Oct, Nov \& Des-98 \\
\hline 8 & BBKU8 & Apr, May, Sep, Oct, Nov \& Des-98 \\
\hline
\end{tabular}

\section{g. Bank Beku Operasional}

Hasil MS menunjukkan bahwa dari 7 bank beku operasional (BBO) yang diobservasi, 6 bank menunjukkan sinyal yang kuat terjadinya bank runs pada periode krisis perbankan pada tahun 1997-1998, sebagaimana tercermin dari nilai probabilitas transisi terjadinya bank runs yang sebesar 1 . Keenam BBO tersebut juga sering memberikan sinyal terjadinya bank runs pada masa sebelum krisis (Tabel 8). Satu bank lainnya (BBO6) hanya pada tahun 1993 pernah memberikan sinyal terjadinya bank runs.

\begin{tabular}{|c|c|c|}
\hline \multicolumn{3}{|r|}{$\begin{array}{l}\text { Tabel } 8 . \\
\text { Hasil Markov-Switching Bank Beku Operasi (BBO) }\end{array}$} \\
\hline No & Bank & Bulan Bank Runs \\
\hline 1 & BBO1 & Aug, Oct \& Nop-88, Jul \& Aug-89, Des-97, Jan, Apr, May \& Jun-98 \\
\hline 2 & BBO2 & Aug \& Nop-89, Feb-93, Nov \& Des97, Jan, Feb, Mar, Apr, May \& Jun-98 \\
\hline 3 & BBO3 & Aug \& Nov-88, Aug \& Des-89, May \& Aug 90, Sep, Oct \& Des-97 \\
\hline 4 & $\mathrm{BBO} 4$ & Aug-90, Jan, Feb \& Apr-91, Jun-92, Des-94, Des-97, Jan-98 \\
\hline 5 & BBO5 & Des-92, Aug, Sep, Oct \& Des-97, Feb, Mar \& Jun-92, Aug, Sep, Oct \& Des-97, Jan-98 \\
\hline 6 & BBO6 & Feb, Mar \& Jun-93 \\
\hline 7 & $\mathrm{BBO} 7$ & $\begin{array}{l}\text { Apr, Sept, Oct \& Nov-92, Jan, Apr, Oct \& Nov-93, Jan, Feb, May, Aug \& Nov-94, } \\
\text { Feb, Sep \& Des-95, Feb-96, Jan, Apr, Aug Sept, Oct \& Des-97, Jan-98 }\end{array}$ \\
\hline
\end{tabular}


Hasil pengujian terhadap kejadian sebenarnya menunjukkan bahwa hasil MS tersebut mampu menjelaskan fenomena bank runs pada bank beku operasional yang terjadi di Indonesia pada periode 1997-1998. Dari hasil keseluruhan observasi, hanya ditemukan 19 kali sinyal yang salah atau $1,26 \%$ dari total observasi.

\section{KESIMPULAN}

Hasil model Markov-Switching (MS) menunjukkan bahwa model MS menghasilkan hasil yang robust sebagai indikator peringatan dini bank runs. Kondisi tersebut tercermin dari hasil pengujian terhadap kejadian sebenarnya pada 102 bank menunjukkan bahwa hasil MS hanya memberikan sinyal yang salah pada kisaran 0,69\% hingga 2,08\%.

Hasil indikator dini bank runs dengan model MS menunjukkan bahwa bank-bank yang mengalami bank runs atau bank bermasalah adalah bank-bank yang berdasarkan hasil MS selalu persisten mengalami bank runs. Model bulanan tesebut dapat dikembangkan menjadi model harian untuk mendeteksi kemungkinan terjadinya bank runs. Sehubungan dengan hal tersebut, disarankan agar model MS digunakan untuk mendeteksi bank runs dalam siklus pengawasan individual bank yang berdasarkan risk-based supervision di Indonesia. IPD dari hasil MS tersebut dalam siklus pengawasan ditempatkan sejajar dengan penilaian risk profile dari masing-masing individual bank, sehingga informasi IPD dapat dioptimalkan bersama-sama dengan penilaian resiko usaha bank lainnya dalam mencegah terjadinya bank runs atau permasalahan lainnya yang dapat membahayakan kelangsungan usaha bank. 


\section{DAFTAR PUSTAKA}

Bank Indonesia, 1997 - 2007, Bank Indonesia Annual Report.

2008, "Indonesian Financial System: 10 years after crisis." DPNP Bank Indonesia working paper.

Demirguc-Kunt, Asli dan Detragiache, Enrica, 1999, "Monitoring Banking Sector Fragility: A Multivariate Logit Approach." IMF Working Paper, No. WP/99/147, Oktober. 2005, "Cross-Country Empirical Studies of Systemic Bank Distress: A Survey." Maret.

Eichengreen, Barry dan Arteta C., 2000, "Banking Crises in Emerging Markets: Presumptions and Evidence". Centre for International Development and Economics Research Working Paper, C00-115, August.

Gonzalez-Hermosillo, Brenda, 1999, "Determinants of Ex-Ante Banking System Distress: A Macro-Micro Empirical Exploration of Some Recent Episodes." IMF Working Paper, No. WP/ 99/33, March.

1990, "Analysis of Time Series Subject to Changes in Regime". Journal of Econometrics 45, hal 39-70.

Kaminsky, Graciela L., 1999, "Currency and Banking Crises: The Early Warnings of Distress." IMF Working Paper, No. WP/99/178, Desember.

, and Carmen M. Reinhart, 1998, "Financial Crises in Asia and Latin America: Then and Now" The American Economic Review, Vol. 88, No. 2, Papers and Proceedings of the Hundred and Tenth Annual Meeting of the American Economic Association (May), pp. 444-448.

, dan Reinhart, Carmen M., 1999, "The Twin Crises: The Causes of Banking and BalanceOf-Payments Problems." The American Economic Review, Vol. 89, No. 3 (Juni), pp. 473 500.

Lindgren, Carl-Johan, Garcia, Gillian, Garcia dan Saal, Matthew, 1996, I."Bank Soundness and Macroeconomic Policy." IMF.

Warjiyo, Perry, 2001, "Bank Failure Management: The Case of Indonesia" APEC Policy Dialogue on Bank Failure Management Paper, Mexico, June 7-8. 


\section{LAMPIRAN 1}

Pada appendix ini akan diuraikan proses estimasi nilai probabilitas transisi yang digunakan sebagai early warning indicators (EWI) of bank runs pada paper ini. Pada prinsipnya, estimasi model Markov-Switching (MS) yang digunakan adalah model MS autoregressive yang dikembangkan oleh Hamilton (1990). Proses estimasi model MS tersebut akan dijelaskan sebagai berikut. Sebagaimana dijelaskan sebelumnya variabel yang digunakan sebagai indikator peringatan dini adalah persentase perubahan bulanan dana pihak ketiga $\left(\mathrm{y}_{\mathrm{t}}\right.$ ). Diasumsikan $\mathrm{y}_{\mathrm{t}}$ mengikuti model autoreggresive $(3)^{9}$ dengan parameter dapat berpindah dari state tenang (tidak terjadi bank runs) ke state terjadi bank runs. Misalkan model autoreggresive tersebut adalah

$$
y_{t}=\alpha_{s_{t}}+\phi_{1, s_{t}} y_{t-1}+\phi_{2, s_{t}} y_{t-2}+\phi_{3, s_{t}} y_{t-3}+\varepsilon_{t}
$$

Dengan $\varepsilon_{t} \sim N\left(0, \sigma_{s_{t}}^{2}\right)$.

Persamaan ini dapat dituliskan dalam bentuk

$$
y_{t}=x_{t}{ }^{\prime} \beta_{s_{t}}+\varepsilon_{t}
$$

Dengan parameter yang digunakan dalam persamaan ini adalah

$$
\begin{aligned}
& x_{t} \equiv\left(1, y_{t-1}, y_{t-2}, y_{t-3}\right)^{\prime} \\
& \beta_{s_{t}} \equiv\left(\alpha_{s_{t}}, \phi_{1, s_{t}}, \phi_{2, s_{t}}, \phi_{3, s_{t}}\right)^{\prime}
\end{aligned}
$$

Fungsi distribusi untuk persamaan ini dapat dituliskan menjadi

$$
p\left(y_{t} \mid z_{t} ; \theta\right)=\frac{1}{\sqrt{2 \pi} \sigma_{a_{t}}} \exp \left\{-\frac{\left(y_{t}-x_{t} \beta_{s_{t}}\right)^{2}}{2 \sigma_{s_{t}}^{2}}\right\}
$$

Fungsi loglikelihood dari persamaan di atas adalah

$$
\log p\left(y_{t} \mid z_{t} ; \theta\right)=-\frac{1}{2} \log 2 \pi-\frac{1}{2} \log \sigma_{s_{t}}^{2}-\frac{\left(y_{t}-x_{t} \beta_{s_{t}}\right)^{2}}{2 \sigma_{s_{t}}^{2}}
$$

\footnotetext{
9 Untuk mengetahui optimal lag dari autoregressive akan digunakan nilai AIC dan SBC.
} 
FOC yang memaksimumkan fungsi log-likelihood di atas adalah

$$
\begin{aligned}
& \frac{\partial \log p\left(y_{t} \mid z_{t} ; \theta\right)}{\partial \beta_{j}}=-2 \frac{y_{t}-x_{t}{ }^{\prime} \beta_{j}}{2 \sigma_{j}^{2}} x_{t}=\frac{\left(y_{t}-x_{t}{ }^{\prime} \beta_{j}\right) x_{t}}{\sigma_{j}^{2}}, s_{t}=j \\
& =0, \text { otherwise }
\end{aligned}
$$

dan

$$
\frac{\partial \log p\left(y_{t} \mid z_{t} ; \theta\right)}{\partial \sigma_{j}^{2}}=-\frac{1}{2} \frac{1}{\sigma_{j}^{2}}+\frac{\left(y_{t}-x_{t}{ }^{\prime} \beta_{j}\right)^{2}}{2 \sigma_{j}^{4}}
$$

Berdasarkan Hamilton, fungsi likelihood dari persamaan di atas adalah

$$
L(\theta)=\sum_{t=1}^{T} \log p\left(y_{t} \mid z_{t} ; \theta\right)
$$

Berdasarkan Hamilton (1990) bahwa fungsi distribusi marginal dari joint distribution dapat dituliskan sebagai berikut. Definisikan

$$
\begin{aligned}
& Y=\left(y_{T}{ }^{\prime}, y_{T-1}{ }^{\prime}, \ldots, y_{1}{ }^{\prime}\right)^{\prime} \\
& S=\left(s_{T}, s_{T-1}, \ldots, s_{1}\right)^{\prime}
\end{aligned}
$$

Maka marginal distribution untuk dua kejadian ini adalah

$$
p(Y ; \theta)=\int_{S} p(Y, S ; \theta)
$$

Kemudian definsikan sebuah fungsi baru yang merupakan ekspektasi dari log-likelihood.

$$
Q\left(\theta_{i+1} ; \theta_{i}, Y\right)=\int_{S} \log p\left(Y, S ; \theta_{i+1}\right) \cdot p\left(Y, S ; \theta_{i}\right)
$$

Fungsi ini sangat berguna dalam memaksimumkan log-likelihood. Berdasarkan Hamilton diketahui bahwa FOC condition akan dipenuhi pada saat

$$
\frac{\partial Q\left(\theta_{i+1} ; \theta_{i}, Y\right)}{\partial \theta_{i+1}}=\int_{S} \frac{\partial \log p\left(Y, S ; \theta_{i+1}\right)}{\partial \theta_{i+1}} \cdot p\left(Y, S ; \theta_{i}\right)=0
$$

Hamilton (1990) membuktikan bahwa persamaan di atas memenuhi FOC yang memaksimumkan fungsi log-likelihood. 
Fungsi log-likelihood dimaksimumkan dengan mendefinisikan fungsi Lagrange berikut

$$
J(\theta)=L(\theta)+\lambda\left(1-\pi_{1}-\pi_{2}-\cdots-\pi_{k}\right)
$$

Dengan fungsi ini akan didapatkan

1. $\frac{\partial J(\theta)}{\partial \beta_{j}}=\frac{\partial L(\theta)}{\partial \beta_{j}}=\sum_{t=1}^{T} \frac{p\left(y_{t}, s_{t}=j ; \theta\right)}{p\left(y_{t} ; \theta\right)} \frac{\left(y_{t}-x_{t}{ }^{\prime} \beta_{j}\right) x_{t}}{\sigma_{j}^{2}}$

$$
=\sum_{t=1}^{T} \frac{\left(y_{t}-x_{t}{ }^{\prime} \beta_{j}\right) x_{t}}{\sigma_{j}^{2}} p\left(s_{t} \mid y_{t} ; \theta\right)=0
$$

Dengan pembagi dikalikan 0 maka

$$
\sum_{t=1}^{T}\left(y_{t}-x_{t}^{\prime} \beta_{j}\right) x_{t} p\left(s_{t}=j \mid y_{t} ; \theta\right)=0
$$

Persamaan ini dapat diselesaikan dengan

$$
\begin{aligned}
& \sum_{t=1}^{T} y_{t} x_{t} p\left(s_{t}=j \mid y_{t} ; \theta\right)-\beta_{j} \sum_{t=1}^{T} x_{t}{ }^{\prime} x_{t} p\left(s_{t}=j \mid y_{t} ; \theta\right)=0 \\
& \hat{\beta}_{j}=\left[\sum_{t=1}^{T} x_{t}{ }^{\prime} x_{t} p\left(s_{t}=j \mid y_{t} ; \theta\right)\right]^{-1} \sum_{t=1}^{T} y_{t} x_{t} p\left(s_{t}=j \mid y_{t} ; \theta\right) \\
& \hat{\beta}_{j}=\left[\sum_{t=1}^{T} x_{t}{ }^{*}{ }^{\prime} x_{t}{ }^{*}\right]^{-1} \sum_{t=1}^{T} x_{t}^{*} y_{t}^{*}
\end{aligned}
$$

Dengan $\quad x_{t}^{*}=x_{t} \sqrt{p\left(s_{t}=j \mid y_{t} ; \theta\right)}$ dan $y_{t}^{*}=y_{t} \sqrt{p\left(s_{t}=j \mid y_{t} ; \theta\right)}$

2. $\frac{\partial}{\partial \sigma_{j}^{2}} J(\theta)=\frac{\partial}{\partial \sigma_{j}^{2}} L(\theta)=\sum_{t=1}^{T} \frac{p\left(y_{t}, s_{t}=j ; \theta\right)}{p\left(y_{t} ; \theta\right)}\left\{-\frac{1}{2 \sigma_{j}^{2}}+\frac{\left(y_{t}-x_{t}{ }^{\prime} \beta_{j}\right)^{2}}{2 \sigma_{j}^{4}}\right\}$

$$
=\sum_{t=1}^{T}\left\{-\frac{1}{2 \sigma_{j}^{2}}+\frac{\left(y_{t}-x_{t}^{\prime} \beta_{j}\right)^{2}}{2 \sigma_{j}^{4}}\right\} p\left(s_{t}=j \mid y_{t} ; \theta\right)=0
$$


Jika persamaan ini diselesaikan maka akan didapatkan

$$
\hat{\sigma}_{j}^{2}=\frac{\sum_{t=1}^{T}\left(y_{t}-x_{t}{ }^{\prime} \hat{\beta}_{j}\right)^{2} p\left(s_{t}=j \mid y_{t} ; \theta\right)}{\sum_{t=1}^{T} p\left(s_{t}=j \mid y_{t} ; \theta\right)}
$$

3. $\frac{\partial}{\partial \pi_{j}} J(\theta)=\frac{\partial}{\partial \pi_{j}} L(\theta)=\sum_{t=1}^{T} \frac{p\left(y_{t}, s_{t}=j ; \theta\right)}{p\left(y_{t} ; \theta\right)}-\lambda$

$$
\begin{aligned}
& =\sum_{t=1}^{T} \frac{p\left(y_{t} \mid s_{t}=j ; \theta\right) p\left(s_{t}=j ; \theta\right)}{p\left(y_{t} ; \theta\right)}-\lambda=0 \\
& s_{t}=j \Rightarrow p\left(s_{t}=j ; \theta\right)=1
\end{aligned}
$$

Jika persamaan tersebut diselesaikan, maka akan didapatkan

$$
\sum_{t=1}^{T} \frac{p\left(y_{t} \mid s_{t}=j ; \theta\right)}{p\left(y_{t} ; \theta\right)}-\lambda=\pi_{j}^{-1} \sum_{t=1}^{T} \frac{p\left(y_{t}, s_{t}=j ; \theta\right)}{p\left(y_{t} ; \theta\right)}-\lambda=\pi_{j}^{-1} \sum_{t=1}^{T} p\left(s_{t}=j \mid \theta\right)-\lambda=0
$$

Jika disederhanakan, maka didapatkan

$$
\sum_{t=1}^{T} p\left(s_{t}=j \mid \theta\right)=\lambda \pi_{j}
$$

Jumlahkan untuk $j=1,2, \ldots, k$, maka didapatkan

$$
\begin{aligned}
& \sum_{t=1}^{T} \sum_{j=1}^{K} p\left(s_{t}=j \mid \theta\right)=\lambda \sum_{j=1}^{K} \pi_{j} \\
& \sum_{t=1}^{T}\{1\}=\lambda .1 \Rightarrow \lambda=T
\end{aligned}
$$

Karena. $\sum_{j=1}^{K} p\left(s_{t}=j \mid \theta\right)=1$ dan $\sum_{j=1}^{K} \pi_{j}=1 \quad$ Maka penaksirnya dapat dituliskan

$$
\hat{\pi}_{j}=\frac{1}{T} \sum_{t=1}^{T} p\left(s_{t}=j \mid \theta\right)
$$

Berdasarkan Hamilton (1990) maka dapat dibuktikan bahwa probabilitas transisi berikut memenuhi FOC. Maka probabilitas transisi dinyatakan oleh persamaan berikut 


$$
p_{i j}^{n+1}=\frac{\sum_{t=1}^{T} p\left(s_{t}=j, s_{t-1}=i \mid y_{t} ; \theta\right)}{\sum_{t=1}^{T} p\left(s_{t-1}=i \mid y_{t} ; \theta\right)}
$$

Dari Hamilton (1990) maka algoritma ini digunakan untuk menaksir parameter dengan arbitrary initial value.

$$
\begin{aligned}
p\left(y_{t} \mid Y_{t-1}\right) & =\sum_{s_{t}=1}^{K} \sum_{s_{t-1}=1}^{K} p\left(s_{t} \mid s_{t-1}\right) p\left(y_{t} \mid s_{t}\right) \rho_{s_{t-1}} \\
p\left(s_{t}, s_{t-1} \mid y_{t}\right) & =\frac{p\left(s_{t} \mid s_{t-1}\right) p\left(y_{t} \mid s_{t}\right) p\left(s_{t-1} \mid y_{t-1}\right)}{p\left(y_{t} \mid Y_{t-1}\right)} \\
& =\frac{p\left(s_{t} \mid s_{t-1}\right) p\left(y_{t} \mid s_{t}\right) \rho_{s_{t-1}}}{p\left(y_{t} \mid Y_{t-1}\right)} \\
p\left(s_{t-1} \mid y_{t}\right) & =\sum_{s_{t}=1}^{K} p\left(s_{t}, s_{t-1} \mid y_{t}\right)
\end{aligned}
$$

$\rho_{s_{t-1}}=p\left(s_{t-1} \mid y_{t-1}\right)$ diambil dari nilai sebelumnya dengan sebagai nilai awal. Nilai ini diambil sebarang sebagai nilai awal dari penaksiran parameter.

Untuk kasus two-state markov change regime sebagaimana digunakan dalam paper ini, nilai transisi probabilitas dihitung sebagai berikut.

$$
\begin{gathered}
p_{11}^{n+1}=\frac{\sum_{t=1}^{T} p\left(s_{t}=1, s_{t-1}=1 ; \theta\right)}{\sum_{t=1}^{T} p\left(, s_{t-1}=1 ; \theta\right)} \\
p\left(s_{t}=1, s_{t-1}=1 \mid y_{t}\right)=\frac{p\left(s_{t}=1 \mid s_{t-1}=1\right) p\left(y_{t} \mid s_{t}=1\right) p\left(s_{t-1}=1 \mid y_{t-1}\right)}{p\left(y_{t} \mid Y_{t-1}\right)} \\
p\left(s_{t}=2, s_{t-1}=1 \mid y_{t}\right)=\frac{p\left(s_{t}=2 \mid s_{t-1}=1\right) p\left(y_{t} \mid s_{t}=2\right) p\left(s_{t-1}=1 \mid y_{t-1}\right)}{p\left(y_{t} \mid Y_{t-1}\right)}
\end{gathered}
$$




$$
\begin{aligned}
& p\left(s_{t}=1, s_{t-1}=1 \mid y_{t}\right)=\frac{p_{11}^{n} \eta_{t \mid s_{t}=1} \rho_{s_{t-1}}^{n}}{p\left(y_{t} \mid Y_{t-1}\right)} \\
& {\left[\begin{array}{ll}
p\left(s_{t}=1, s_{t-1}=1 \mid y_{t}\right) & p\left(s_{t}=2, s_{t-1}=1 \mid y_{t}\right) \\
p\left(s_{t}=1, s_{t-1}=2 \mid y_{t}\right) & p\left(s_{t}=2, s_{t-1}=2 \mid y_{t}\right)
\end{array}\right]} \\
& \left.\quad\left\{\begin{array}{cc}
\rho_{s_{0}=1} & 0 \\
0 & \rho_{s_{0}=2}
\end{array}\right]\left[\begin{array}{cc}
p_{11} & p_{12} \\
p_{21} & p_{22}
\end{array}\right]\left[\begin{array}{cc}
\eta_{t \mid s_{t}=1} & 0 \\
0 & \eta_{t \mid s_{t}=2}
\end{array}\right]\right\} / p\left(y_{t} \mid Y_{t-1}\right)
\end{aligned}
$$

$p\left(y_{t} \mid Y_{t-1}\right)=\sum_{s_{t}=1}^{K} \sum_{s_{t-1}=1}^{K} p_{i j}^{n} \eta_{t \mid s_{t}} \rho_{s_{t-1}}^{n}=\left[\begin{array}{ll}\rho_{s_{0}=1} & \rho_{s_{0}=2}\end{array}\right]\left[\begin{array}{ll}p_{11} & p_{12} \\ p_{21} & p_{22}\end{array}\right]\left[\begin{array}{l}\eta_{t \mid s_{t}=1} \\ \eta_{t \mid s_{t}=2}\end{array}\right]$

$p\left(s_{t-1}=1 \mid y_{t}\right)=\sum_{s_{t}=1}^{K} p\left(s_{t}, s_{t-1}=1 \mid y_{t}\right)$

$$
p\left(s_{t-1}=1 \mid y_{t}\right)=p\left(s_{t}=1, s_{t-1}=1 \mid y_{t}\right)+p\left(s_{t}=2, s_{t-1}=1 \mid y_{t}\right)
$$

$p\left(s_{t-1}=1 \mid y_{t}\right)=\frac{\left[p\left(s_{t}=2 \mid s_{t-1}=1\right) p\left(y_{t} \mid s_{t}=2\right)+p\left(s_{t}=1 \mid s_{t-1}=1\right) p\left(y_{t} \mid s_{t}=1\right)\right] p\left(s_{t-1}=1 \mid y_{t-1}\right)}{p\left(y_{t} \mid Y_{t-1}\right)}$

$$
=\frac{\left[p_{12} \eta_{t \mid s_{t}=2}+p_{11} \eta_{t \mid s_{t}=1}\right] p\left(s_{t-1}=1 \mid y_{t-1}\right)}{p\left(y_{t} \mid Y_{t-1}\right)}
$$

$$
\begin{aligned}
& {\left[\begin{array}{l}
p\left(s_{t-1}=1 \mid y_{t}\right) \\
p\left(s_{t-1}=2 \mid y_{t}\right)
\end{array}\right]=\left[\begin{array}{ll}
p\left(s_{t}=1, s_{t-1}=1 \mid y_{t}\right) & p\left(s_{t}=2, s_{t-1}=1 \mid y_{t}\right) \\
p\left(s_{t}=1, s_{t-1}=2 \mid y_{t}\right) & p\left(s_{t}=2, s_{t-1}=2 \mid y_{t}\right)
\end{array}\right]\left[\begin{array}{l}
1 \\
1
\end{array}\right]} \\
& =\left[\begin{array}{l}
p\left(s_{t}=1, s_{t-1}=1 \mid y_{t}\right)+p\left(s_{t}=2, s_{t-1}=1 \mid y_{t}\right) \\
p\left(s_{t}=1, s_{t-1}=2 \mid y_{t}\right)+p\left(s_{t}=2, s_{t-1}=2 \mid y_{t}\right)
\end{array}\right] \\
& p_{11}^{n+1}=\frac{\sum_{t=1}^{T} \frac{p_{11} \eta_{t \mid s_{t}=1} p\left(s_{t-1}=1 \mid y_{t-1}\right)}{p\left(y_{t} \mid Y_{t-1}\right)}}{\sum_{t=1}^{T} \frac{\left(p_{12} \eta_{t \mid s_{t}=2}+p_{11} \eta_{t \mid s_{t}=1}\right) p\left(s_{t-1}=1 \mid y_{t-1}\right)}{p\left(y_{t} \mid Y_{t-1}\right)}} \\
& =\left[\begin{array}{ll}
p\left(s_{t}=1, s_{t-1}=1 \mid y_{t}\right) & p\left(s_{t}=2, s_{t-1}=1 \mid y_{t}\right) \\
p\left(s_{t}=1, s_{t-1}=2 \mid y_{t}\right) & p\left(s_{t}=2, s_{t-1}=2 \mid y_{t}\right)
\end{array}\right] \text {. }
\end{aligned}
$$

$$
\left[\begin{array}{cc}
{\left[p\left(s_{t}=1, s_{t-1}=1 \mid y_{t}\right)+p\left(s_{t}=2, s_{t-1}=1 \mid y_{t}\right)\right]^{-1}} & 0 \\
0 & {\left[p\left(s_{t}=1, s_{t-1}=2 \mid y_{t}\right)+p\left(s_{t}=2, s_{t-1}=2 \mid y_{t}\right)\right]^{-1}}
\end{array}\right]
$$


Dimana $p\left(s_{t}=1 \mid s_{t-1}=1\right)$ didapatkan dari transition matrix sementara itu $p\left(y_{t} \mid s_{t}=1\right)$ dari persamaan conditional distribution. Nilai awal yang digunakan adalah $p\left(s_{0}=1 \mid y_{0}\right)$. Dengan cara yang sama dapat juga digunakan untuk mencari menaksir besarnya $p_{22}$. Nilai awal yang dapat digunakan untuk menaksir parameter adalah besarnya

$$
\left\{\alpha_{1}, \alpha_{2}, \phi_{1,1}, \phi_{2,1}, \phi_{3,1}, \phi_{1,2}, \phi_{2,2}, \phi_{3,2}, p_{11}, p_{22}, \rho_{1}, \rho_{2}, \sigma_{1}^{2}, \sigma_{2}^{2}\right\}
$$




\section{LAMPIRAN 2}

\section{Gambar Perubahan Dana Bank dan Ergodic Probability Ke Bank Run State}

\section{Bank Pemerintah (BP)}
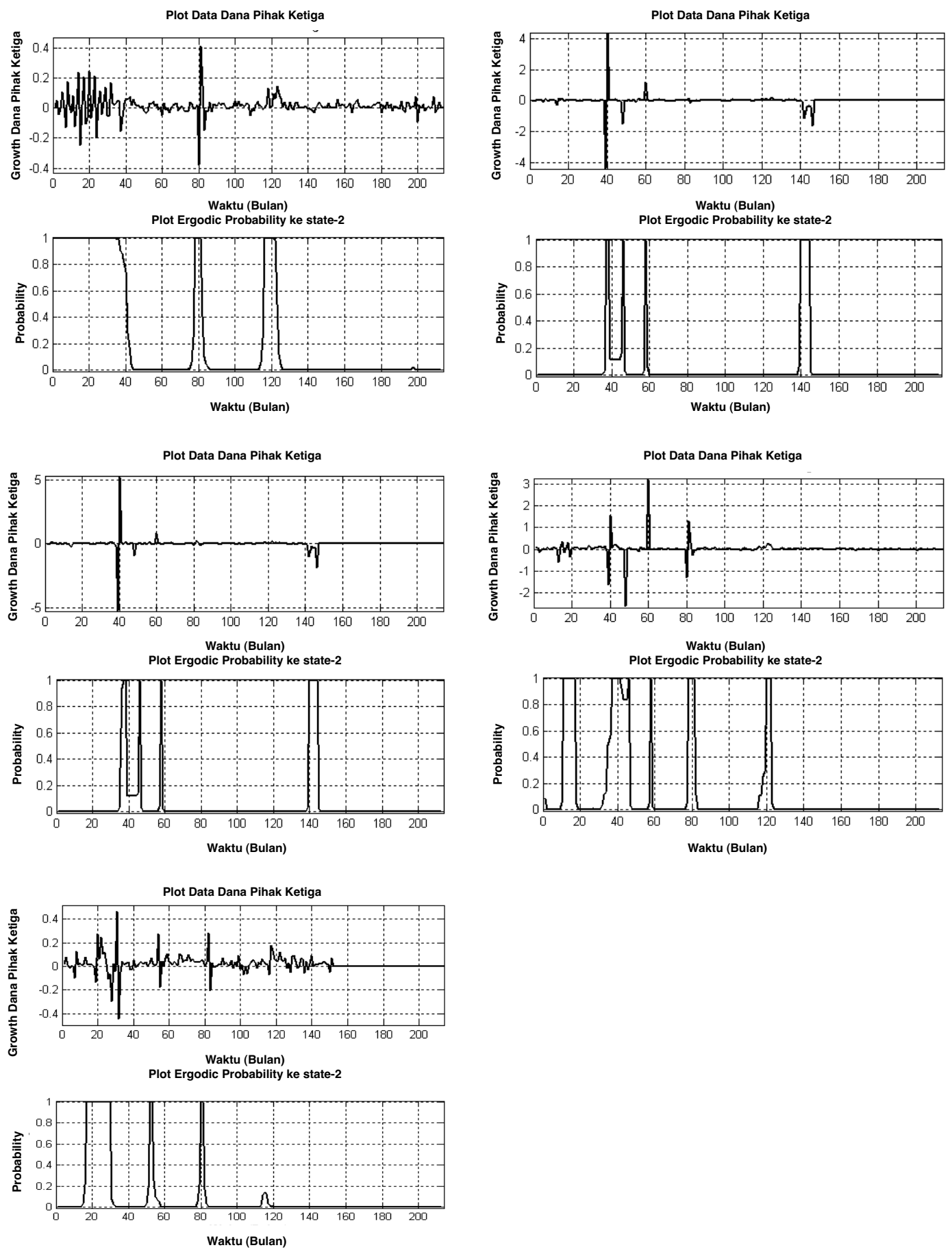


\section{Bank Swasta Devisa (BSD)}
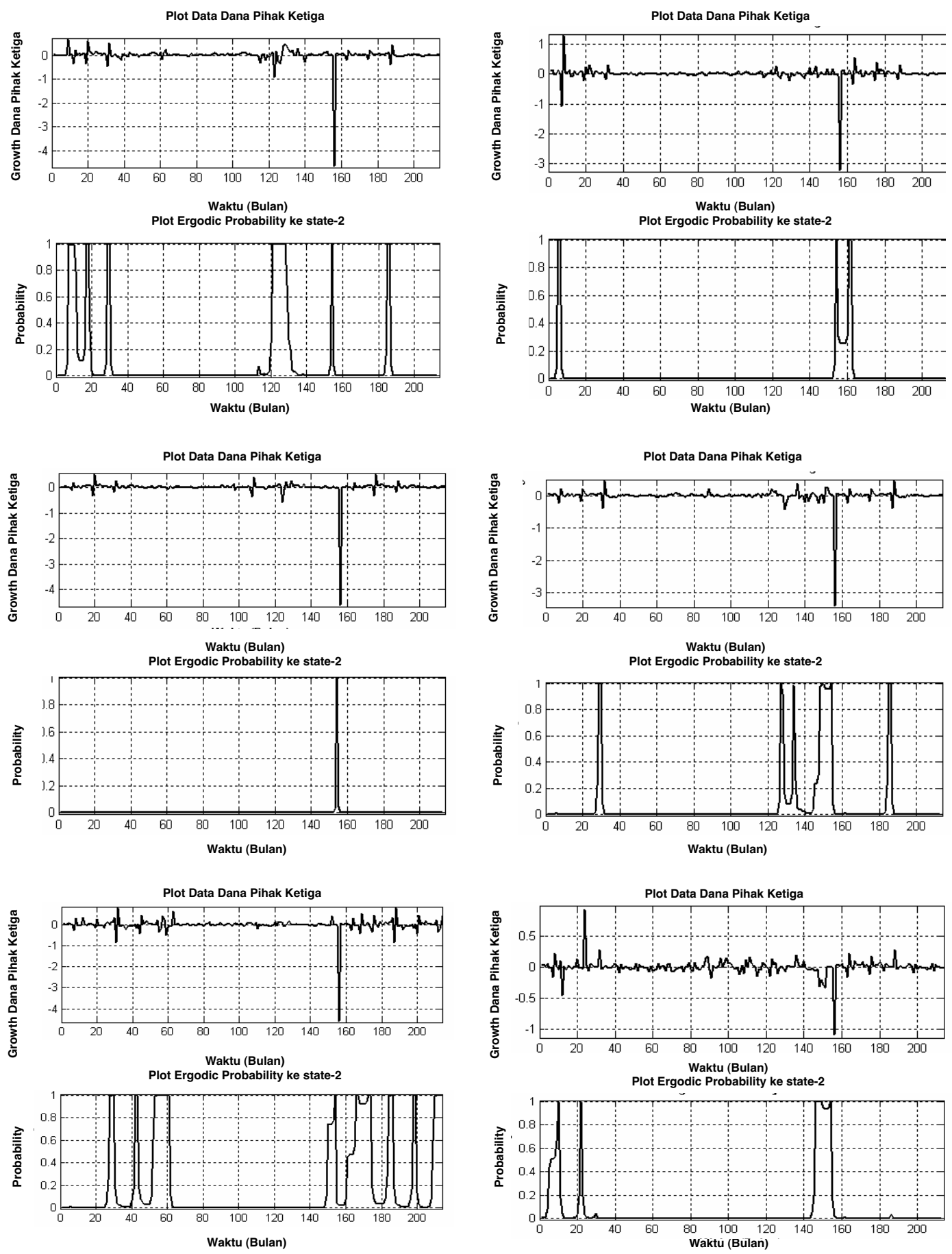

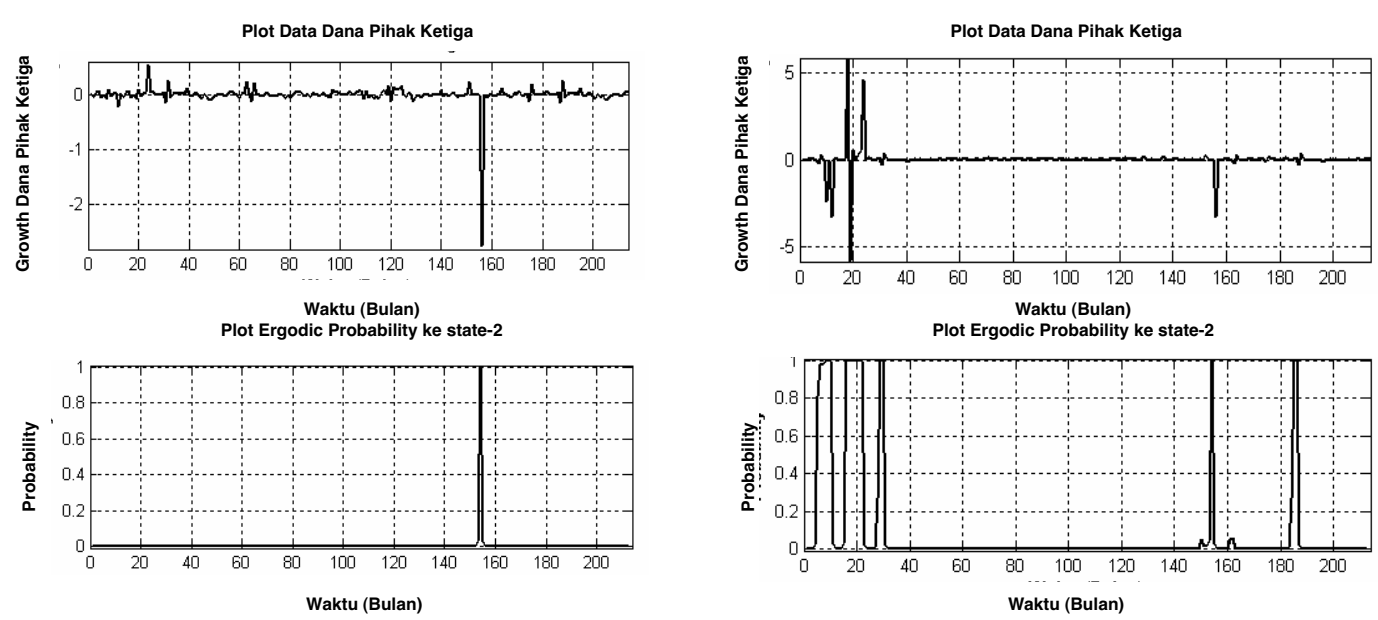

\section{Bank Swasta Non Devisa (BSND)}
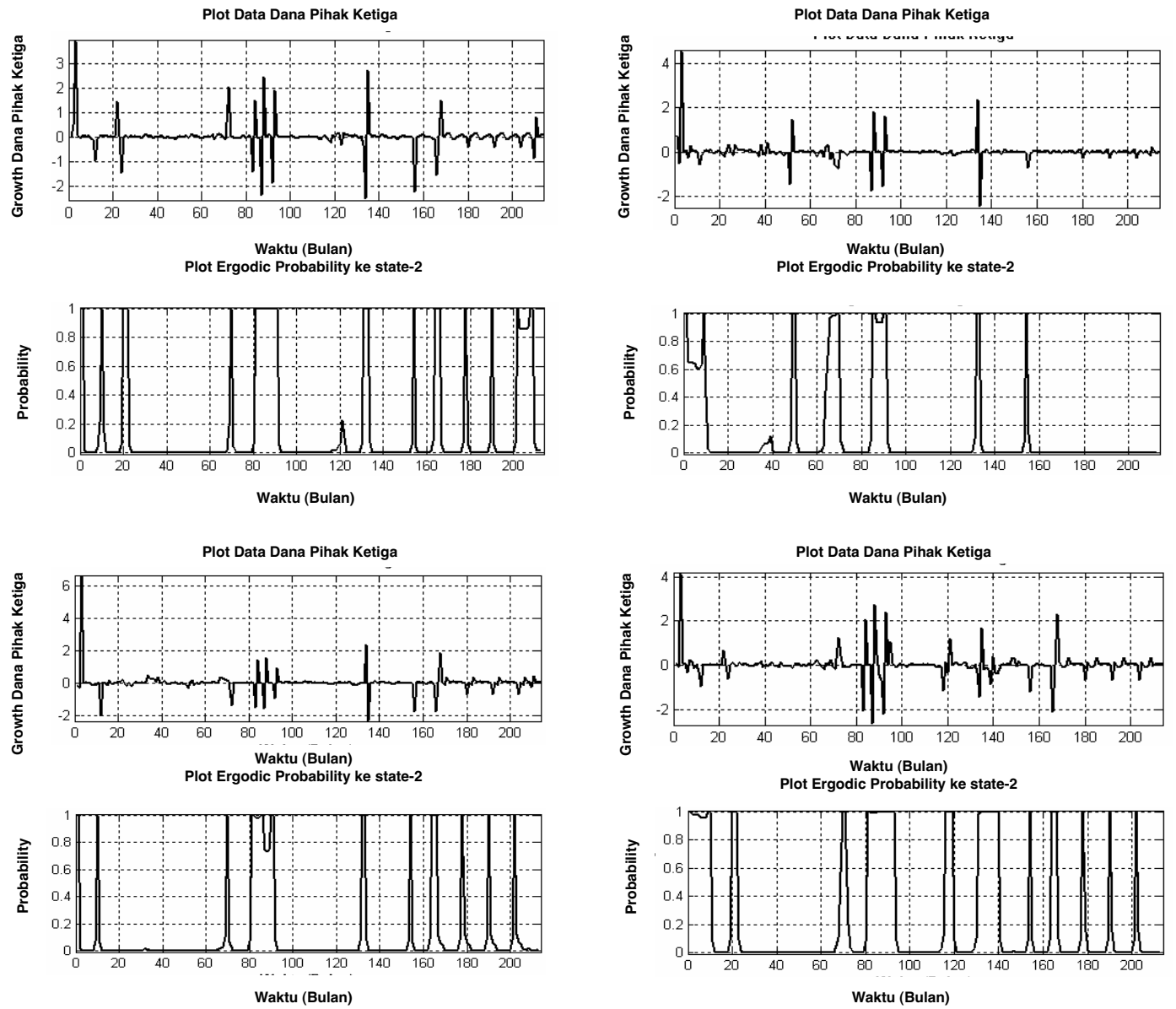

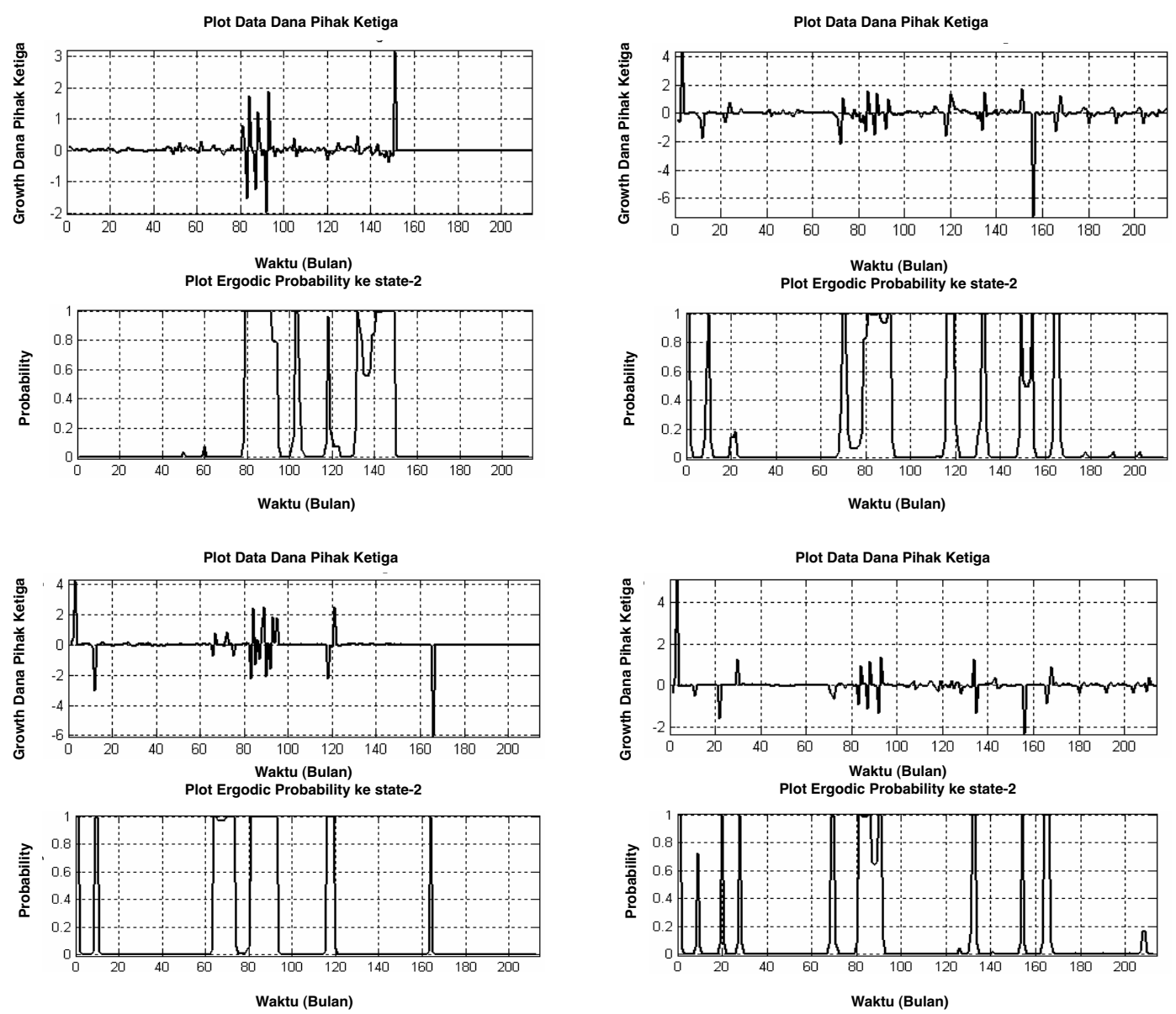

\section{Bank Asing (BA)}
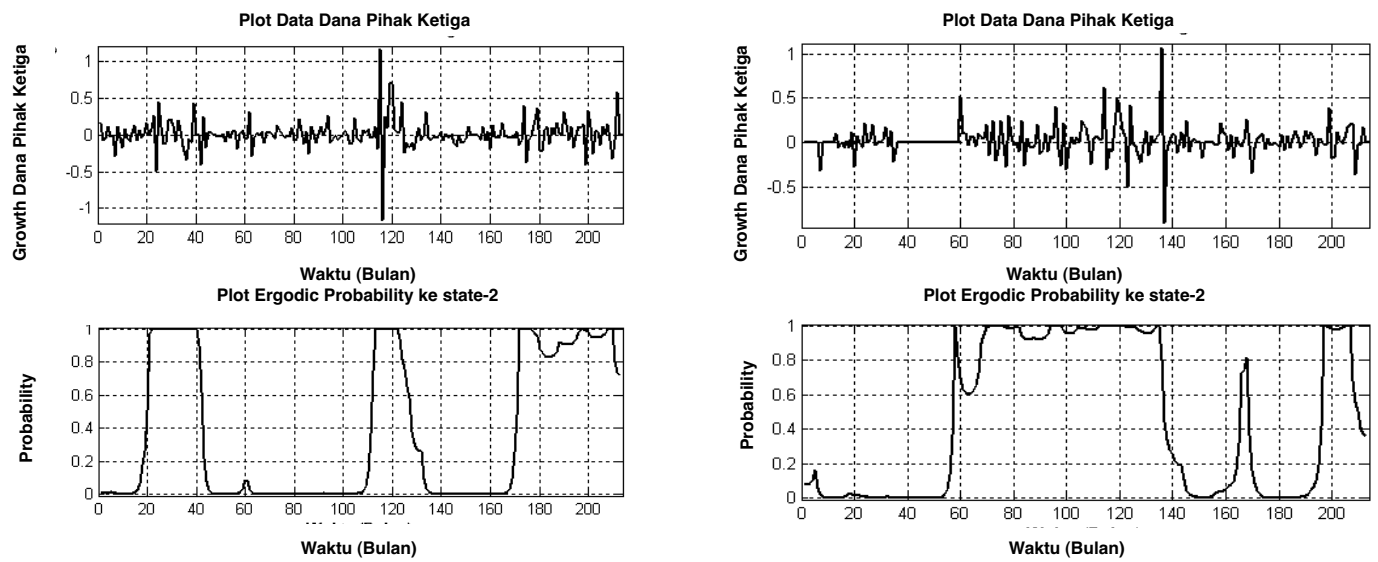

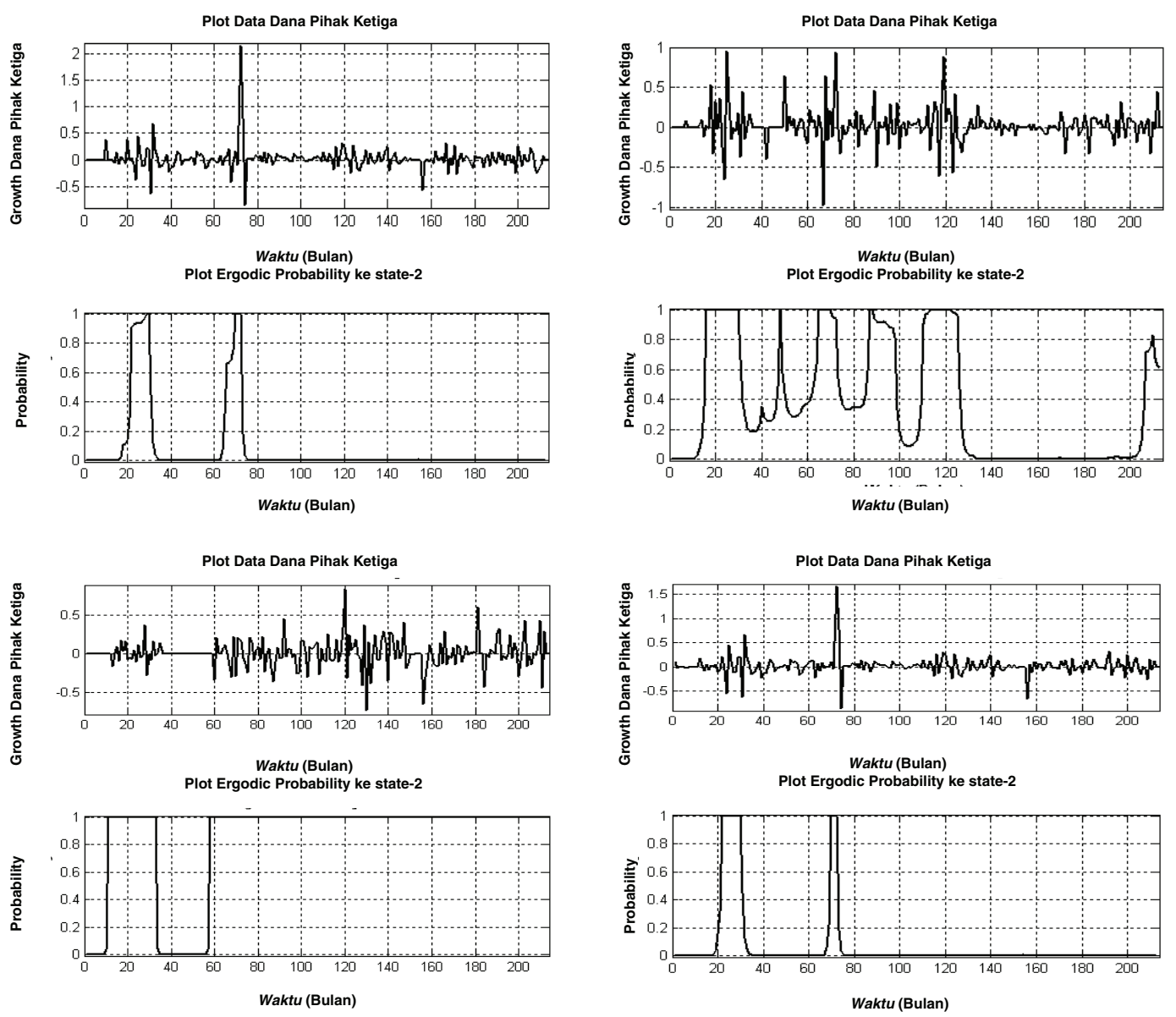

\section{Bank Campuran (BC)}
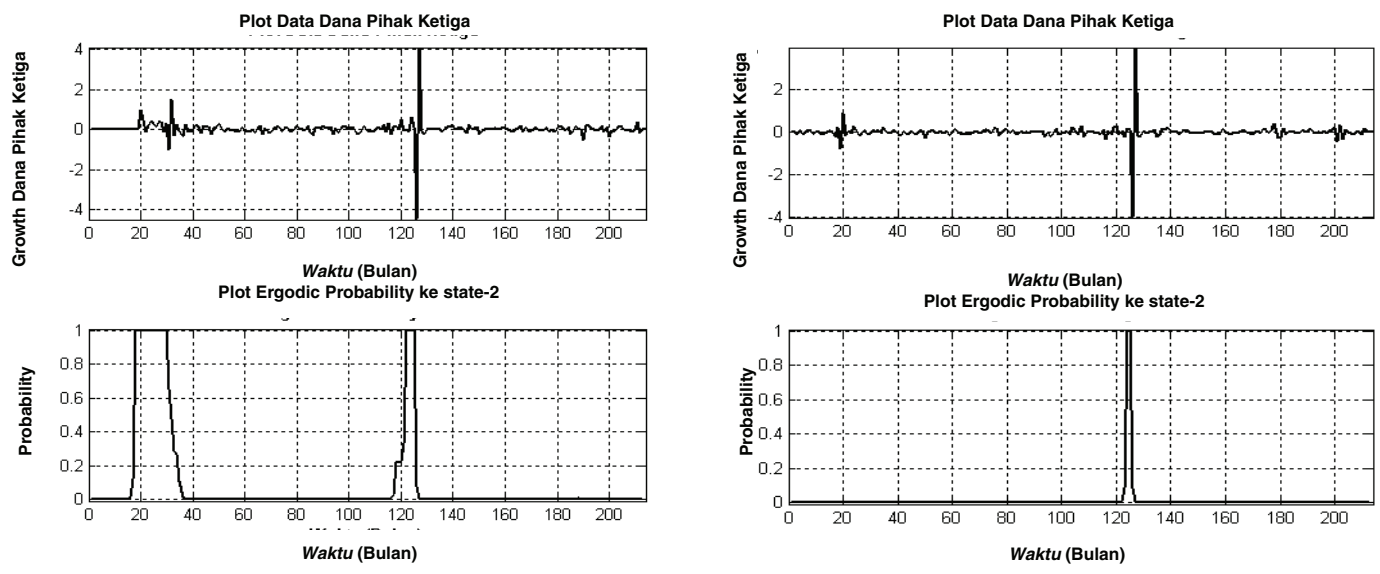

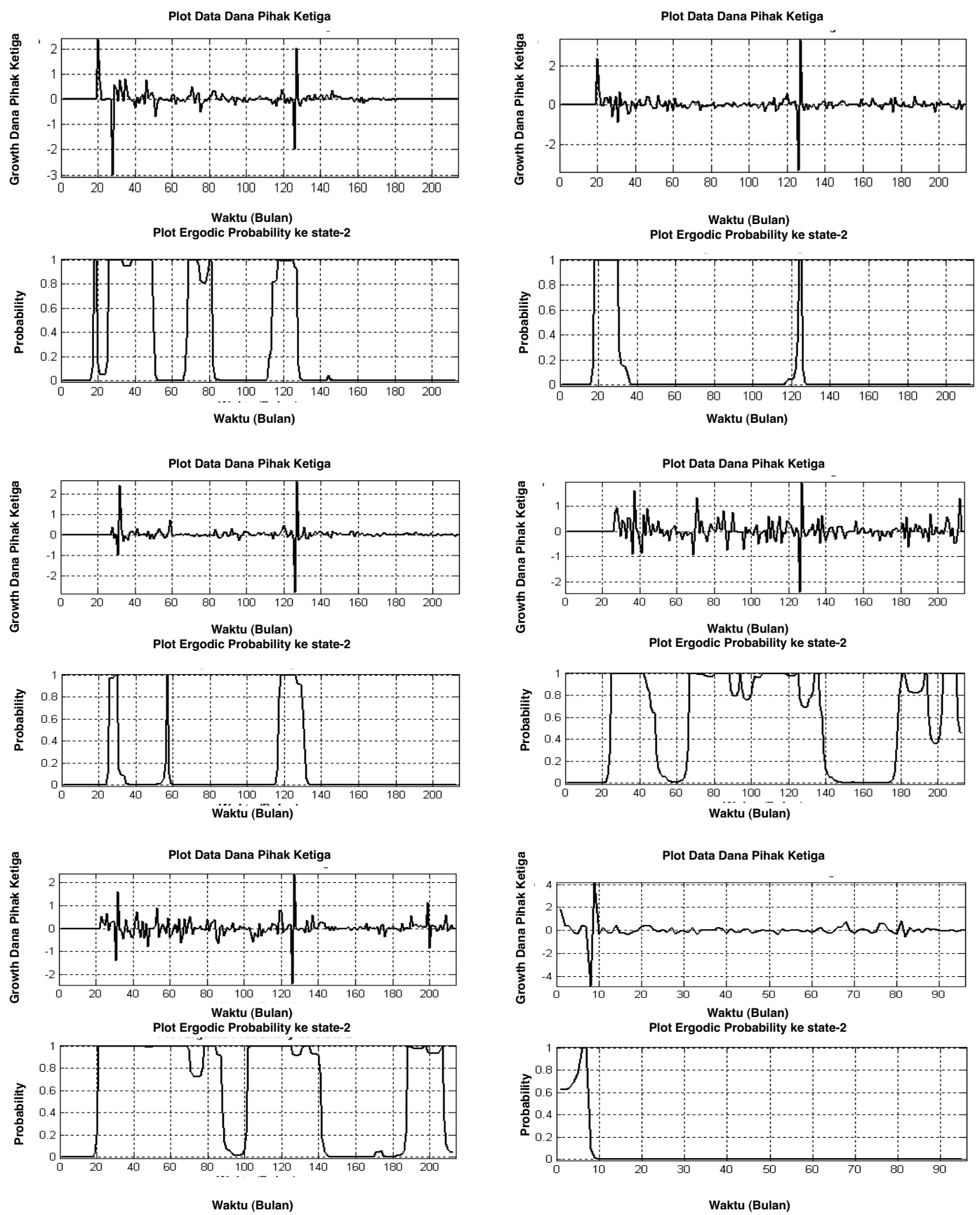


\section{Bank Beku Kegiatan Usaha (BBKU)}
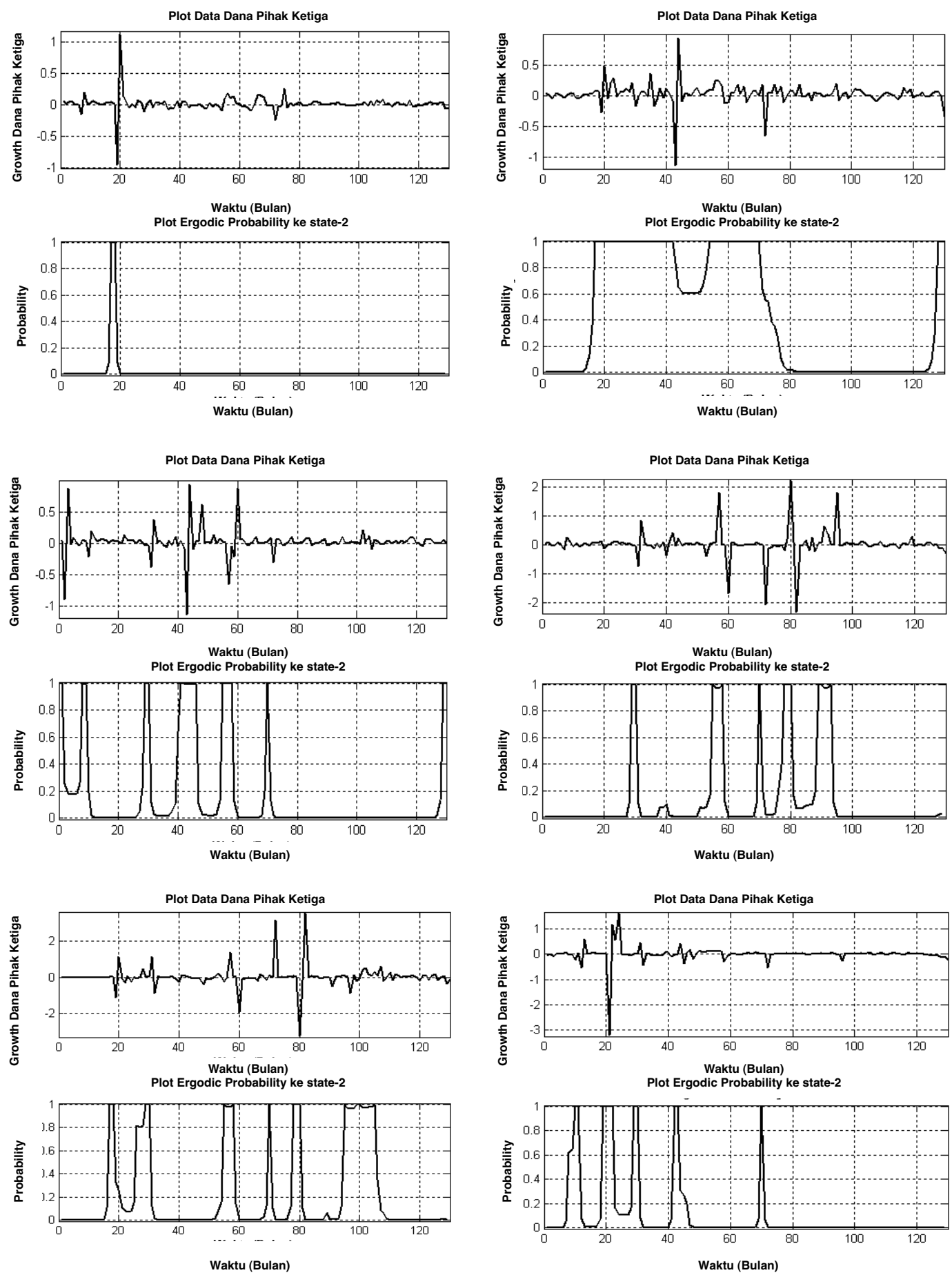


\section{BankBeku Operasi (BBO)}
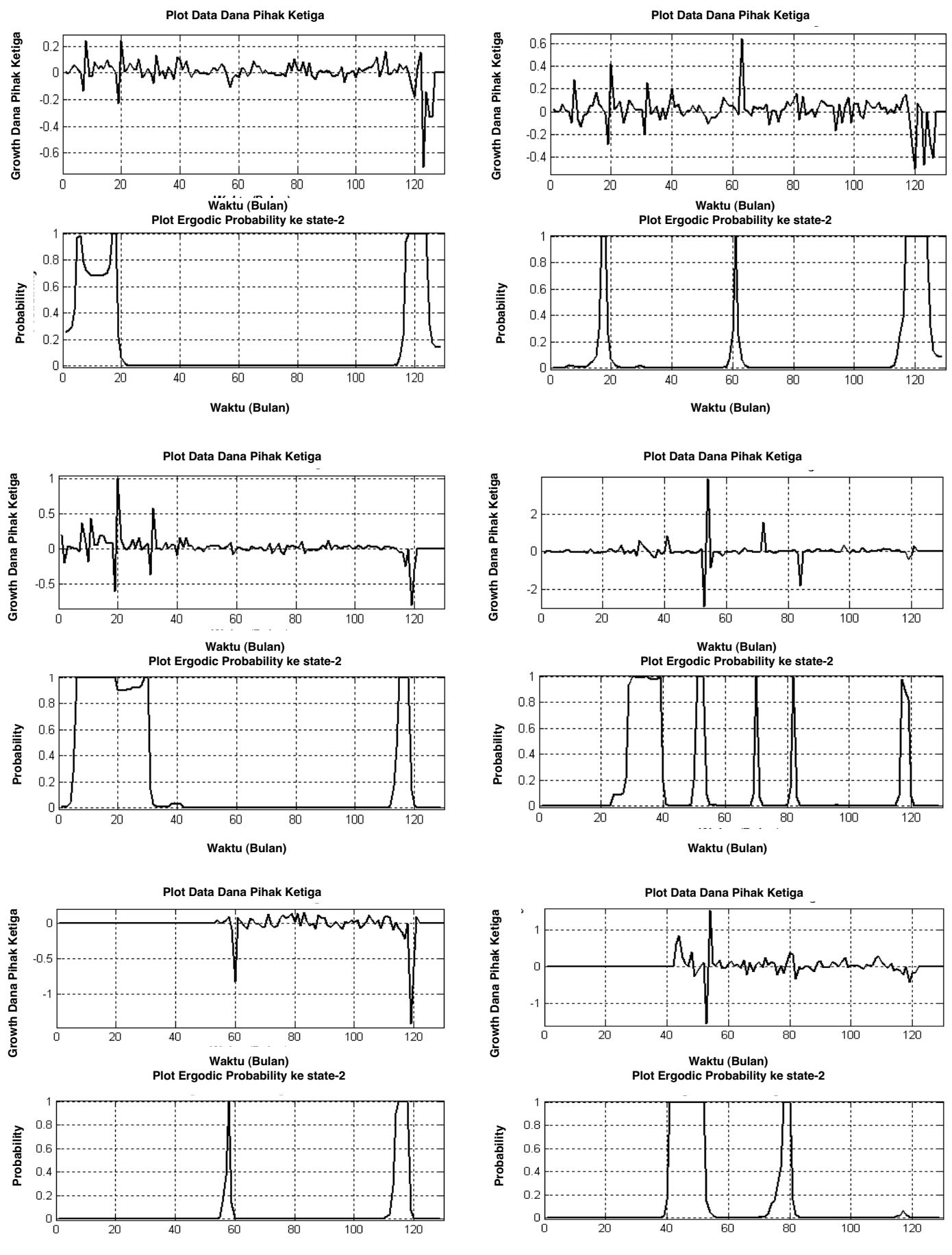

Waktu (Bulan)

Waktu (Bulan) 
Halaman ini sengaja dikosongkan 